\title{
Major Features of the Summer Near-Surface Circulation of Western Baffin Bay, 1978 and 1979
}

\author{
D.B. FISSEL, ${ }^{1}$ D.D. LEMON ${ }^{1}$ and J.R. BIRCH ${ }^{1}$
}

\begin{abstract}
In the summers of 1978 and 1979, an extensive physical oceanographic program was carried out in western Baffin Bay and Lancaster Sound. Data collected include satellite-tracked drifter measurements, CTD profiles and time series of subsurface currents. They indicate that the near-surface circulation of the area is dominated by the southward-flowing Baffin Current. This current, observed to extend at least as far north as Lady Ann Strait $\left(76^{\circ} \mathrm{N}\right)$ and south to Cape Dyer $\left(67^{\circ} \mathrm{N}\right)$, is largely confined to within $100 \mathrm{~km}$ of the coastline. It varies in both intensity and width with the strongest flows occurring where the current follows a cyclonic intrusion into and out of eastern Lancaster Sound; here in the core of the current the median near-surface $(4$ to $11 \mathrm{~m})$ speeds are $75 \mathrm{~cm} / \mathrm{s}$, decreasing to $50 \mathrm{~cm} / \mathrm{s}$ at $40 \mathrm{~m}$ depth and $25 \mathrm{~cm} / \mathrm{s}$ at $250 \mathrm{~m}$ depth. To the east of Devon, Bylot and Baffin islands, the current is well-defined, but generally less intense with typical near-surface speeds of $30 \mathrm{~cm} / \mathrm{s}$. Important spatial variations occurred in the circulation of the area. In eastern Lancaster Sound, two distinct and alternating flow patterns were observed in the strong intrusive current in the summer of 1979. Transient large-scale meanders of the circulation were detected in the offshore portion of the Baffin Current off the east coasts of Bylot and Baffin islands. Between the eastern coastline of Bylot Island and the core of the southeasterly flowing Baffin Current, anticyclonic eddies of approximately $20 \mathrm{~km}$ diameter occasionally occurred.
\end{abstract}

Key words: Baffin Bay, Baffin Current, circulation, Lancaster Sound, oceanography, surface currents, sub-surface currents

\begin{abstract}
RESUMÉ Durant la période estivale 1978 et 1979, un programme extensif d'océanographie physique fut effectué dans la partie ouest de la baie de Baffin et du détroit de Lancaster. Les données recueillies comprennent des mesures de dérivation suivi par satellite, les profiles CTD (Courant, Temps, Distance) et des séries temporelles des courants sous la surface. Elles indiquent que le mouvement près de la surface du territoire à l'étude est dominé par le courant de Baffin s'écoulant du côté sud. Ce courant qui fut observé au nord jusqu'au du détroit de Lady Ann $\left(76^{\circ} \mathrm{N}\right)$ et au sud jusqu'au cap Dyer $\left(67^{\circ} \mathrm{N}\right)$ est largement confiné à l'intérieur des $100 \mathrm{~km}$ du littoral. Il varie aussi bien en intensité qu'en largeur avec une force maximum qui survien lorsque le courant suit une intrusion cyclonique à l'intérieur et à l'extérieur du détroit de Lancaster; ici, dans le centre du courant, la vitesse moyenne près de la surface $(4$ à $11 \mathrm{~m})$ ést de $75 \mathrm{~cm} / \mathrm{s}$, diminuant à $50 \mathrm{~cm} / \mathrm{s} \mathrm{à}$ $40 \mathrm{~m}$ de profondeur et $25 \mathrm{~cm} / \mathrm{s}$ à $250 \mathrm{~m}$ de profondeur. A l'est des îles Devon, Bylot et Baffin, le courant est bien défini, mais généralement moins intense avec une vitesse type près de la surface de $30 \mathrm{~cm} / \mathrm{s}$. D'importantes variations spatiales sont survenues dans la circulation dans la region. A l'est du détroit de Lancaster, deux patrons d'écoulement distinct et alternatif ont été observés dans le fort courant intrusif de l'êté 1979. Des méandres transitoires à large échelle furent enregistrés au large du courant de Baffin à l'extérieur des côtes de îles Bylot et Baffin. Également, entre le littoral est de l'île Bylot et le centre de l'écoulement est du courant de Baffin, des tourbillons anticycloniques d'environ $20 \mathrm{~km}$ de diametre sont survenus occasionnellement.
\end{abstract}

Traduit par Guy Fouquet, Aménatech inc., Sherbrooke.

\section{INTRODUCTION}

In 1978 and 1979, a major study of the physical oceanography of Lancaster Sound and western Baffin Bay was carried out as part of the Eastern Arctic Marine Environmental Studies (EAMES). The program was designed to define the surface and near-surface circulation of the area as part of an environmental impact assessment of potential offshore oil and gas exploration and to provide information for engineering purposes. In this paper the major features of the summer near-surface circulation are described, based on the results of the 1978 and 1979 field studies. Figure 1 shows the location of the study area; place names referred to in the text are identified on the more detailed map of Figure 2.

The oceanographic data previously collected in this area have been reviewed by Dunbar (1951), Dunbar et al. (1967), Muench (1971), Walker (1977) and most recently in detail by Fissel et al. (1980). The existence of a persistent southerlyflowing current in western Baffin Bay was known as early as about 1850; ships beset in ice in eastern Parry Channel were carried south along the Baffin Island coast towards
Davis Strait. Water mass measurements, taken by the Godthaab expedition in 1928 (Kiilerich, 1939) and by the Northland expedition in 1940 (Barnes, 1941), allowed construction of charts of the dynamic topography. The charts revealed the two main currents of Baffin Bay: the northwardflowing West Greenland Current to the east, and the stronger southward-flowing Baffin Current to the west. The 1928 data suggested an intrusion of flow into Lancaster Sound, which was later supported by data collected in the 1950 s and 1960s. Direct current measurements were lacking but the Baffin Current was believed to have speeds of the order of $20 \mathrm{~cm} / \mathrm{s}$. The first series of direct current measurements in Lancaster Sound was made in 1974 by the Canadian Hydrographic Service; the mooring was close to shore and tides and bathymetric effects dominated the record. Current meter records obtained in eastern Lancaster Sound in 1977 (Fissel and Wilton, 1978), were the first to indicate the strength (up to $112 \mathrm{~cm} / \mathrm{s}$ ) and the variability of the cross-sound flows. Generally, however, direct current measurements were sparse and little was known of the detailed character of the Baffin Current, particularly its temporal and spatial variability, prior to 1978 . 


\section{Bathymetry}

The centre of Baffin Bay is characterized by a flatbottomed basin of more than $2300 \mathrm{~m}$ depth (Fig. 1). The basin is bounded on the west by a relatively narrow, steep-sided shelf along the east coast of Baffin Island. Water depths on the shelf are generally less than $200 \mathrm{~m}$, although it is cut by several underwater canyons up to $800 \mathrm{~m}$ deep. The basin shoals more gradually to the northwest towards the entrance of Lancaster Sound, where depths average 700 to $800 \mathrm{~m}$. Lancaster Sound itself has steep sides and gradually shoals westward to a sill of less than $200 \mathrm{~m}$ depth in Barrow Strait.

East of Devon Island a broad bank with depths of less than $350 \mathrm{~m}$ is partially separated from the coastline by a trench up to $600 \mathrm{~m}$ deep which issues from Jones Sound via Lady Ann Strait. The trench ends at Philpots Island. The east side of the bank is bounded by the channel extending southward from Smith Sound. This channel is limited by a sill of $250 \mathrm{~m}$ depth in Kane Basin (north of Smith Sound).

\section{Ice Cover}

With the exception of the North Water polynya (Dunbar et al., 1967), Lancaster Sound and western Baffin Bay are covered with pack ice throughout the winter season. Clearing usually begins in late June with the expansion of the North Water to the south and west into the mouth of Lancaster Sound. Further clearing of Lancaster Sound and Barrow Strait depends upon the position at which the commonly observed ice edge between landfast and mobile sea ice has been established during the course of the previous winter (Marko, 1981). The edge usually stabilizes at one of a number of locations between Cape Warrender and Barrow Strait. East of the edge Lancaster Sound becomes almost entirely ice-free, until the ice edge breaks up (normally in July and August) and allows further discharges of ice from the west. The discharges take the form of ice streams and variously sized ice fields. Baffin Bay clears from the north and southeast, leaving most of the bay clear by early September with the possible exception of a remnant of the pack in the centre of the bay and a coastal strip along southeastern Baffin Island. The ice along the Baffin Island coast is generally the last to clear, and in some years never completely clears. Throughout the open-water season, pack ice is discharged into Baffin Bay from the passages of the archipelago; as well, icebergs are present throughout the western half of the bay.

Both 1978 and 1979 were severe ice years, 1978 being worse than 1979. In 1978, the ice edge in Lancaster Sound stabilized at Cape Warrender and remained there until late August. After its disintegration, discharges of ice from the archipelago produced significant amounts of pack ice in eastern Lancaster Sound and along the Bylot and Baffin island coasts. In 1979 the Lancaster Sound ice edge stabilized further to the west, off Croker Bay, and broke up earlier,

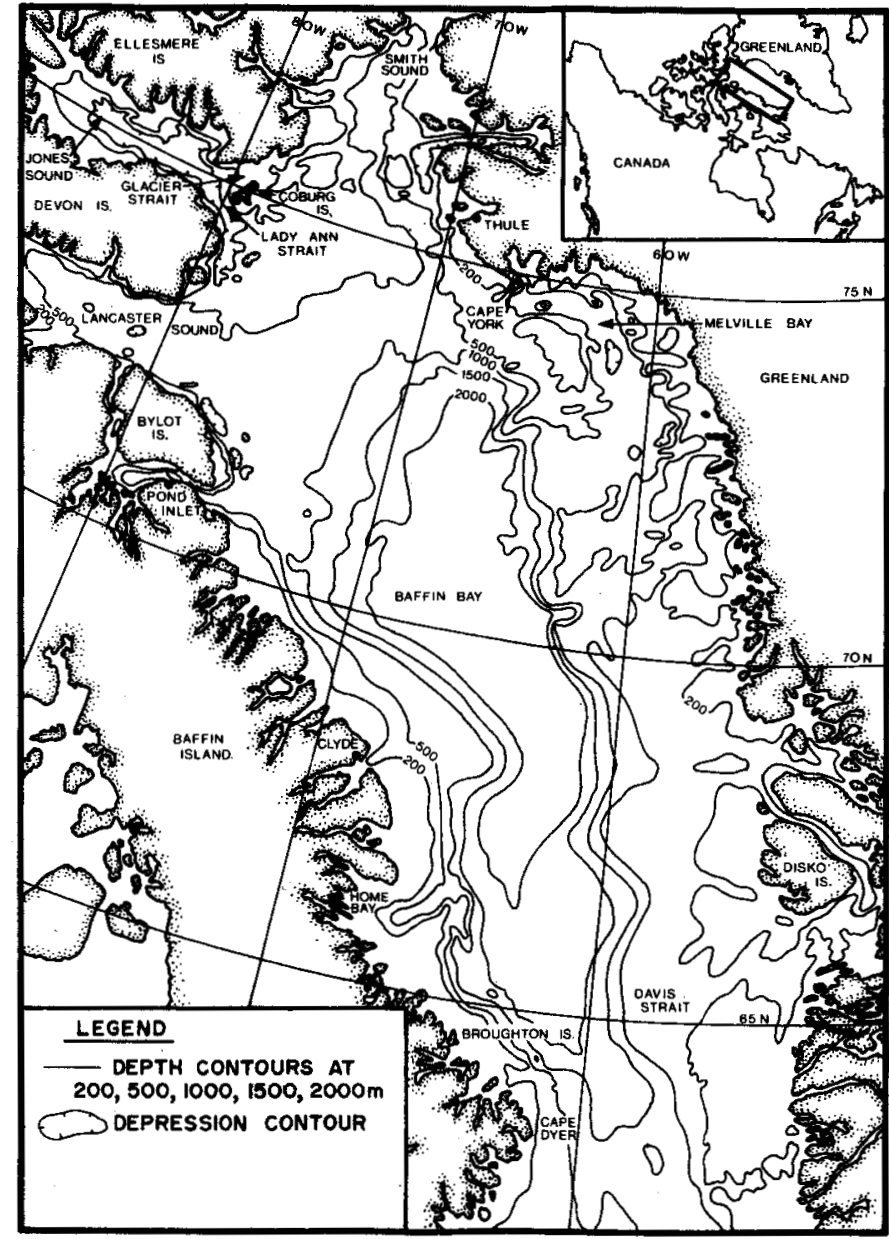

FIG. 1. Bathymetry of Baffin Bay and adjacent water bodies.

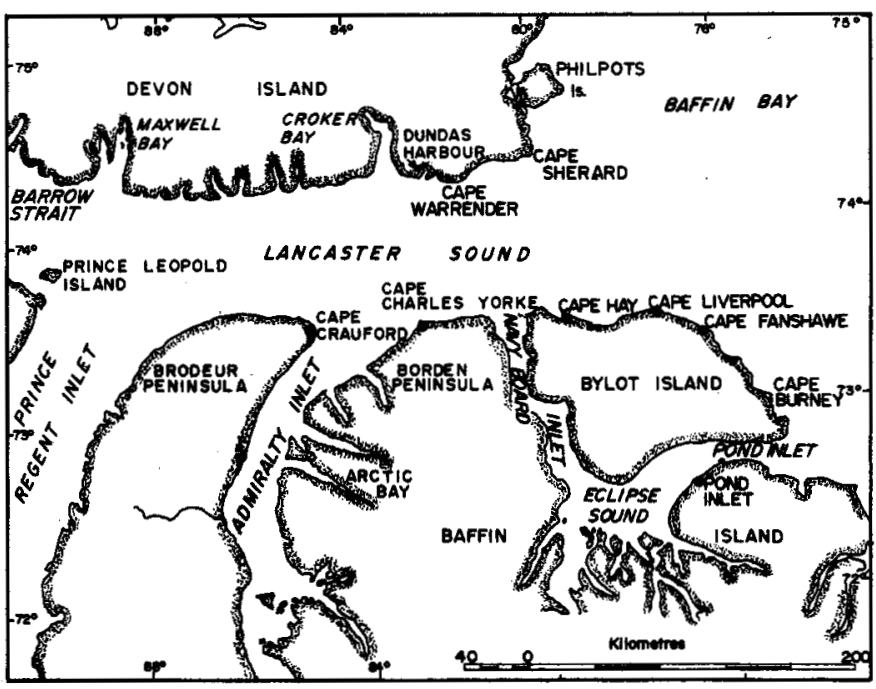

FIG. 2. Place names in the Lancaster Sound region.

but the position was still relatively far to the east when compared to more "normal" ice years. Again, discharges of ice from the archipelago occasionally resulted in heavy concentrations of pack ice in Lancaster Sound and along the Baffin Island coast. 


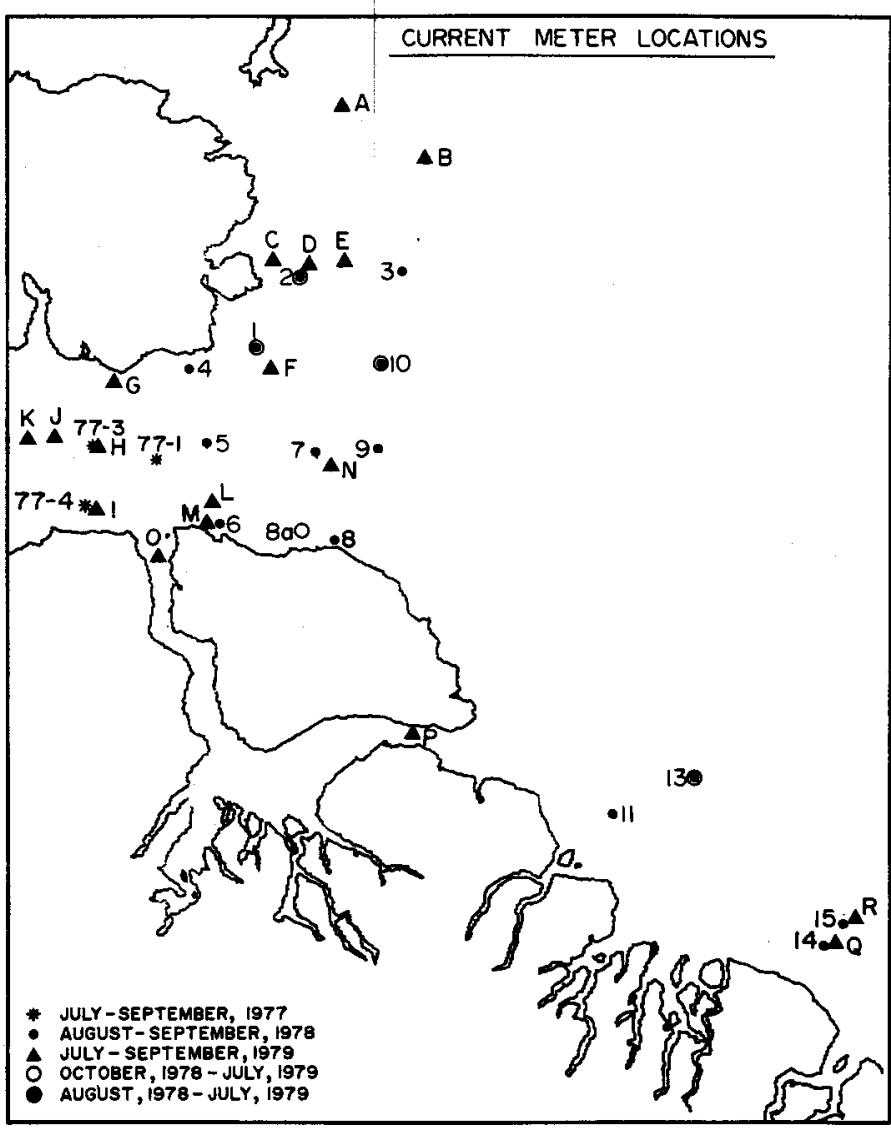

FIG. 3. Locations of summer current meter moorings 1977-1979. Stations marked $\bullet$ were operated during August and September 1978 only. Those marked 1 were operated during August and September 1978, and then redeployed and operated from October 1978 to July 1979 . Those marked o were operated from October 1978 to July 1979 only. Those marked $\Delta$ were operated from July to October 1979 . (The three marked * were moorings operated in August and September 1977 for another project, but whose data are considered in this paper).

\section{DATA COLLECTION AND METHODS}

This paper is primarily oriented toward a description of the surface circulation as determined from current meter, drifter and CTD (conductivity, temperature, depth) data collected during the EAMES program. In addition to the EAMES data, some use was made of the current meter data collected during the summer of 1977 (Fissel and Wilton, 1978) at three sites in Lancaster Sound (Fig. 3). The EAMES studies conducted in 1978 covered locations from the entrance to Jones Sound in the north to the vicinity of the southern boundary of Baffin Bay, as shown by moored current meter, and CTD locations plotted in Figures 3 and 4. In addition, 15 satellite-tracked drifting buoys were released to the east of Devon Island and in eastern Lancaster Sound. Some current meter moorings used during the summer were redeployed for the winter in October 1978, and were recovered in July 1979 at four sites off the mouth of Lancaster Sound and at a single site off the east coast of Baffin Island. On the basis of the results obtained in summer 1978, changes were made in 1979 summer programs in eastern Lancaster Sound and off eastern Devon and Bylot islands, in order to better resolve the intense but relatively narrow circulation features of these areas.

In the summer of 1979 , the area coverage of the program was expanded to include a CTD survey across northern Baffin Bay, CTD stations in Jones Sound, and a drifter and CTD study of western and central Lancaster Sound (Figs. 3 and 5). The number of satellite-tracked drifters released in 1979 was increased to 35 , with 18 of these being released off the east coast of Devon Island. Of the remaining drifters, 14 were deployed in western and central Lancaster Sound and three were released off the northeast coast of Bylot Island. In addition, physical oceanographic studies of nearshore zones were carried out from shore-based camps at Cape Warrender on Devon Island and Cape Fanshawe on Bylot Island, along with a ship-based survey off Cape Hay on Bylot Island.

The current meter data were used primarily to establish the temporal variability of the flow, while the drifter and CTD data were used to determine its spatial structure. Large-scale circulation patterns were inferred from dynamic topography charts constructed from the CTD data using a

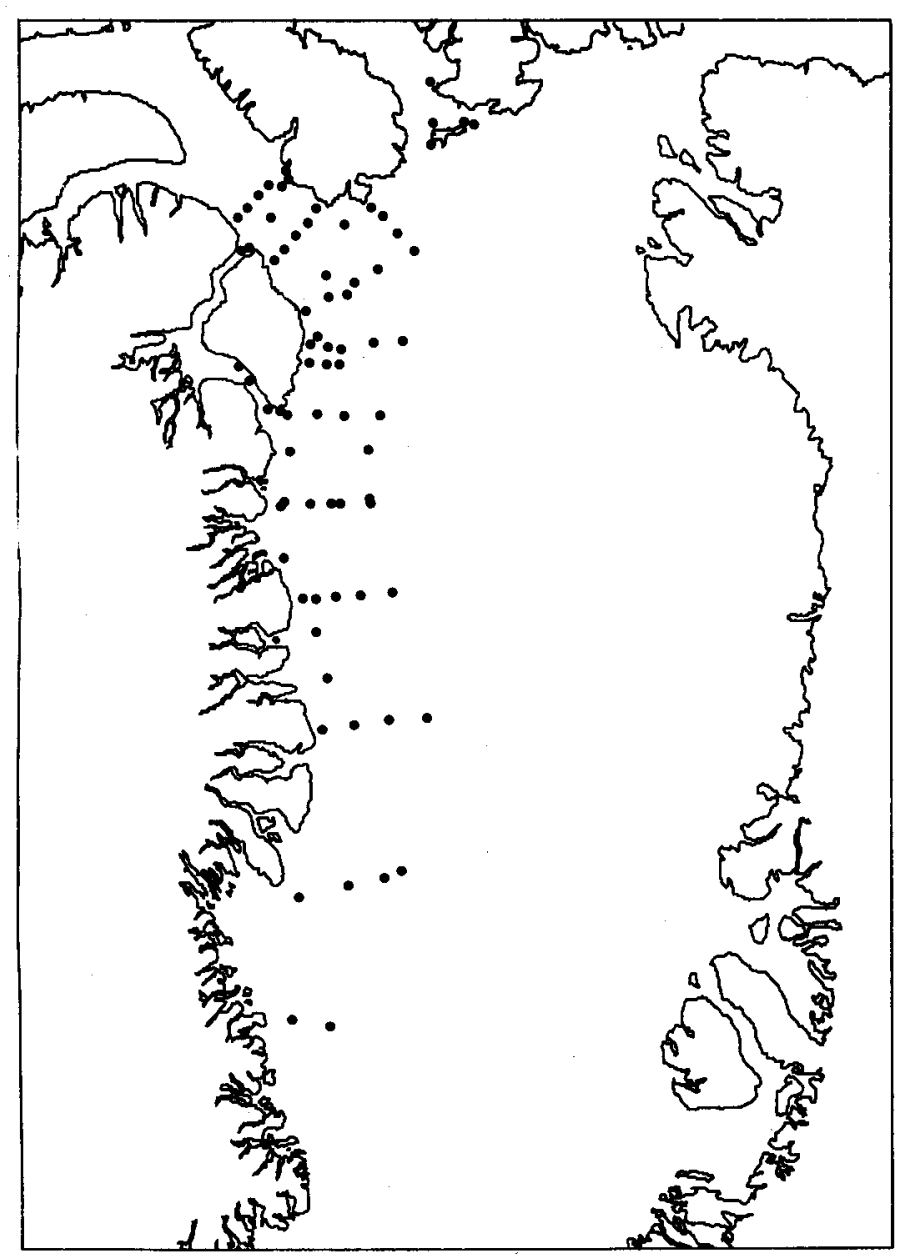

FIG. 4. Locations of CTD stations in 1978 . The majority of the stations were occupied three times during the period from July to October, with the stations south of Bylot Island being occupied only once for the two most southerly lines and twice for the remainder. 
300 decibars (dbar) reference level. (In the ocean, pressures in dbars are approximately equivalent to depths in $\mathrm{m}$.) The $300 \mathrm{dbar}$ level was chosen for convenience, in order to avoid extensive extrapolation into areas shallower than the reference level. It is by no means a true level of no motion, although a significant portion of the current shear appears to exist between the surface and that level. The dynamic topography charts were therefore used to establish circulation patterns and not to determine absolute values of surface currents.

Details of the methodology used in these oceanographic studies can be found in Birch (1980a, b), Fissel (1980), Fissel and Birch (1980), Fissel and Wilton (1980) and Lemon (1980).

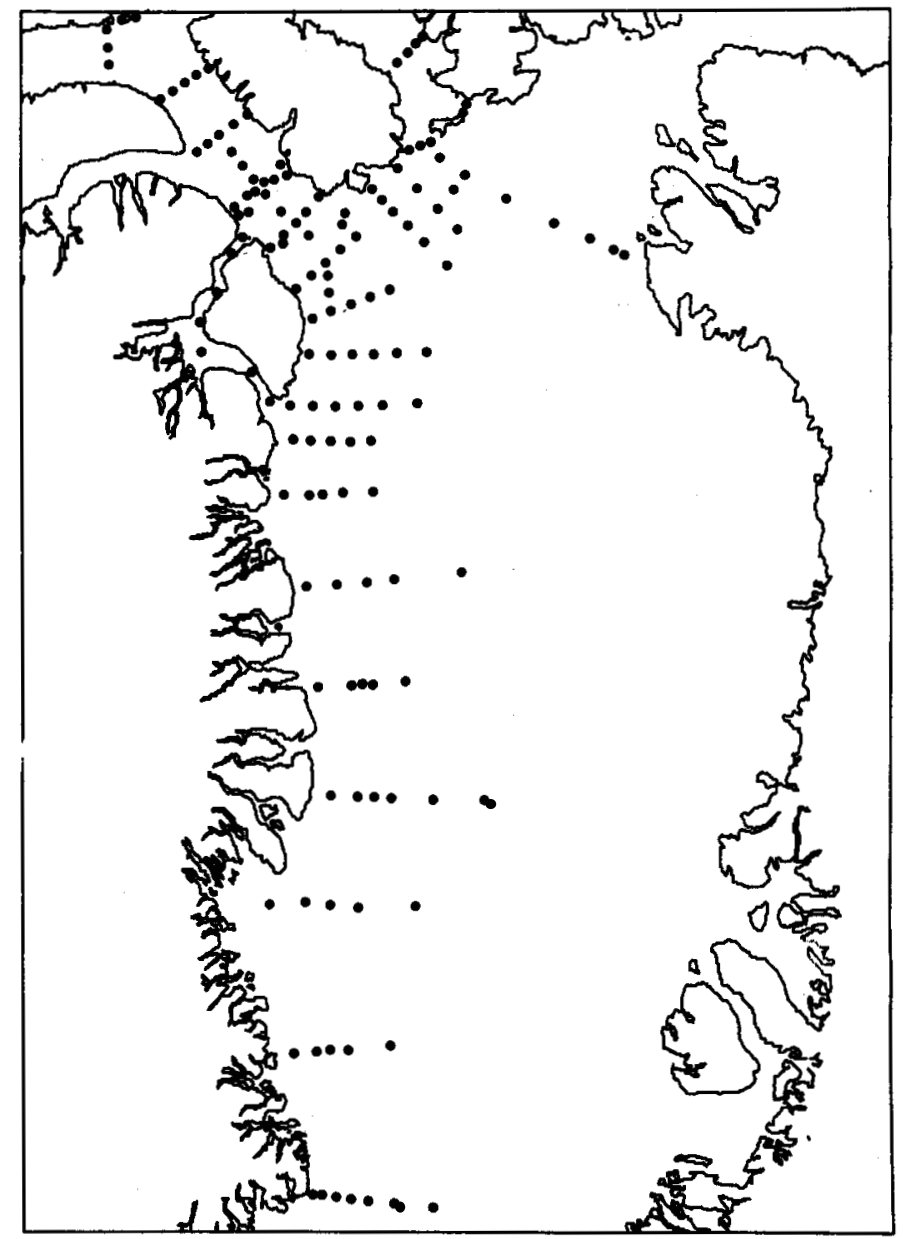

FIG. 5. Locations of CTD stations in 1979. Stations were occupied from July to October, with most of the stations in Lancaster Sound and its approaches being occupied four times. The remainder of the stations were taken either once or twice.

\section{RESULTS}

The southeastward-flowing Baffin Current dominates the surface circulation of western Baffin Bay. Although the term Baffin Current has previously been restricted to the southward flows along the eastern Baffin Island coast, the data collected in this study show it to be an identifiable phenomenon as far north as Lady Ann Strait. Originating primarily with Arctic Ocean water flowing into northern Baffin Bay through Smith, Jones and Lancaster sounds, along with a contribution from the remnants of the West Greenland Current, the Baffin Current flows southeastward along the western side of Baffin Bay into Davis Strait.

\section{Characteristics of Water Masses}

The waters of western Baffin Bay and Lancaster Sound have been divided into three layers (Muench, 1971):

(a) The Arctic Water, defined by low temperatures $\left(0^{\circ} \mathrm{C}\right.$ to $\left.-1.8^{\circ} \mathrm{C}\right)$ and low salinites $(<31 \%$ to about $34 \%$ ). It generally extends to depths of 200 to $300 \mathrm{~m}$ in Baffin Bay and Lancaster Sound.

(b) The Atlantic Water, defined by warmer temperatures $\left(0^{\circ} \mathrm{C}\right.$ to $\left.>2^{\circ} \mathrm{C}\right)$ and higher salinities $(34.2 \%$ o to $34.5 \%$ ). It generally extends from the bottom of the Arctic Water to depths of 600 to $700 \mathrm{~m}$ in Lancaster Sound and 1200 to $1300 \mathrm{~m}$ in northern Baffin Bay.

(c) The Deep Water, defined by low temperatures $\left(0^{\circ} \mathrm{C}\right.$ to $\left.0.4^{\circ} \mathrm{C}\right)$ and nearly uniform salinities $(34.48 \%$ o) . This layer extends from the bottom of the Atlantic Water in Baffin Bay to the seabed.

Data collected during the EAMES program conform to the above description of the structure of the water column, with two exceptions: the near-surface layer and the interface between the Arctic and Atlantic water masses. During the summer season, the upper portion of the Arctic Water (depths less than $75 \mathrm{~m}$ ) becomes modified by surface processes such as solar heating, wind mixing and ice melt. The result is a highly variable surface layer overlying the uniformly cold bulk of Arctic Water. An example of such an upper layer may be seen in the temperature crosssection for 25 August 1979(Fig. 6), extending offshore from eastern Bylot Island. The depth of the modified layer in this example is between 25 and $50 \mathrm{~m}$, with the exception of

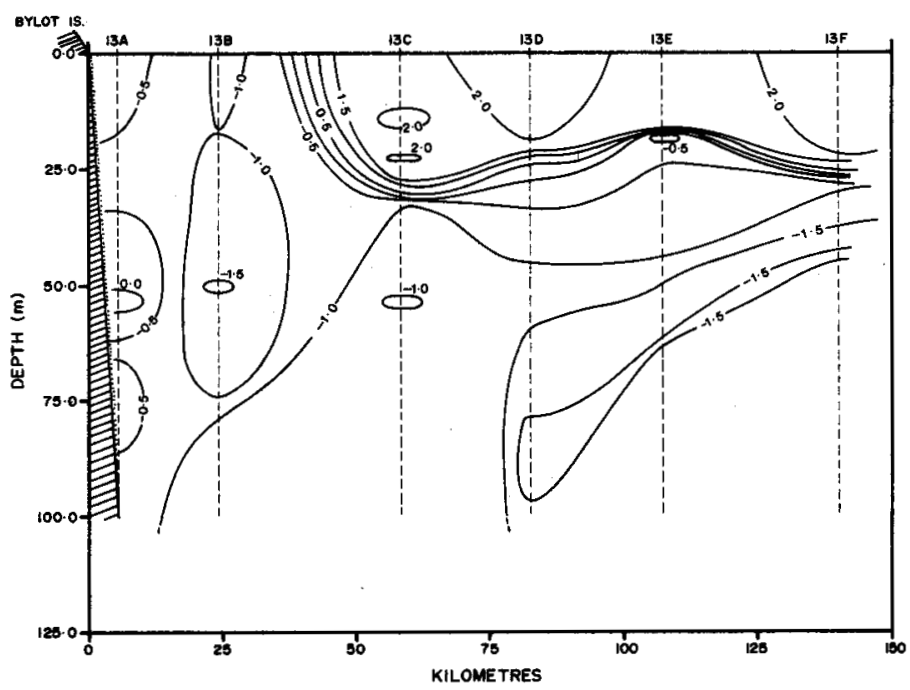

FIG. 6. Cross-section of temperature in the upper $100 \mathrm{~m}$, for a line of stations running east of Bylot Island, 25-26 August 1979. 
the area within $40 \mathrm{~km}$ of the Bylot Island shoreline where the influence of colder, fresher water flowing out of Lancaster Sound may be seen. Within the upper zone, temperatures may range from $-1.0^{\circ} \mathrm{C}$ to $3.0^{\circ} \mathrm{C}$ or greater, and salinities from $28.0 \%$ o to $32.5 \%$. Surface salinities may be even lower in areas where runoff or local ice melt are important.

Because of the prevailing low water temperatures (even in the near-surface layer), solar heating does not have a great influence on the density stratification, which is mainly determined by the salinity. Near coastlines, subsurface warm layers can be produced when colder, fresher water from runoff or ice melt overlays warmer, more saline water.

In offshore zones where the upper layer is not as subject to the advective processes associated with the strong coastal currents, it usually preserves its well-mixed character, and appears to deepen through the season (see Figure 7, for example, which shows successive occupations of a station $30 \mathrm{~km}$ east of Devon Island). Because there is no significant salinity change in the upper zone, the heated surface water becomes rapidly mixed throughout the upper layer, resulting in quite uniformly warm temperatures through its entire depth.

The transition zone between the cold Arctic Water and the warmer, more saline Atlantic Water is the site of a great deal of interleaving structure in the temperature profile. The majority of the profiles taken during the EAMES program show this structure (Fissel et al., 1980; Lemon, 1980). Within the deep thermocline, a series of warm layers alternates with a series of cooler layers. The thickness of the layers ranges from 6 to $30 \mathrm{~m}$, and the temperature differences are up to $0.5^{\circ} \mathrm{C}$. Interleaving is present at very reduced amplitude in the salinity trace, some portions of which are step-like in nature. Some of these steps may be due to double diffusion, as the combination of the temperature interleavings and a monotonically increasing salinity profile results in cold, fresh layers overlying warm, salty layers. Double diffusion in this case leads to a sharpening of the interface and a step-like profile.

\section{Conditions East of Devon Island}

Earlier studies using dynamic topography derived from bottle cast data (Kiilerich, 1939; Bailey, 1957) have revealed generally southerly flows through this area. The origin of these flows appears to be a combination of a broad southerly flow to the east of Coburg Island (originating from Smith Sound and the continuation of the West Greenland Current [Muench, 1971]) and a more intense southeasterly flow through Lady Ann Strait. The current flowing through Lady Ann Strait represents Arctic Water flowing from Jones Sound, along with water entering eastern Jones Sound from Baffin Bay through Glacier Strait (Herlinveaux, 1974; Barber and Huyer, 1977).

The near-surface waters flowing out of Lady Ann Strait are colder and less saline than water at similar depths in Baffin Bay, apparently a result of the influence of land runoff and ice melt. These waters can be traced south indicating that the outflow of Jones Sound remains near the east coast of Devon Island. The strength of the Jones Sound outflow is variable. During three CTD occupations in 1979 the surface baroclinic flow (relative to $300 \mathrm{dbar}$ ) in the southern half of Lady Ann Strait varied between 0 and $15 \mathrm{~cm} / \mathrm{s}$. Figure 8 is a plot of two surface drifter trajectories in the area. Drifter number 1982 moved south at speeds up to $100 \mathrm{~cm} / \mathrm{s}$. The speed probably represents an upper bound for the current, as the surface portion of the drifter may have been carried by wind-driven ice.

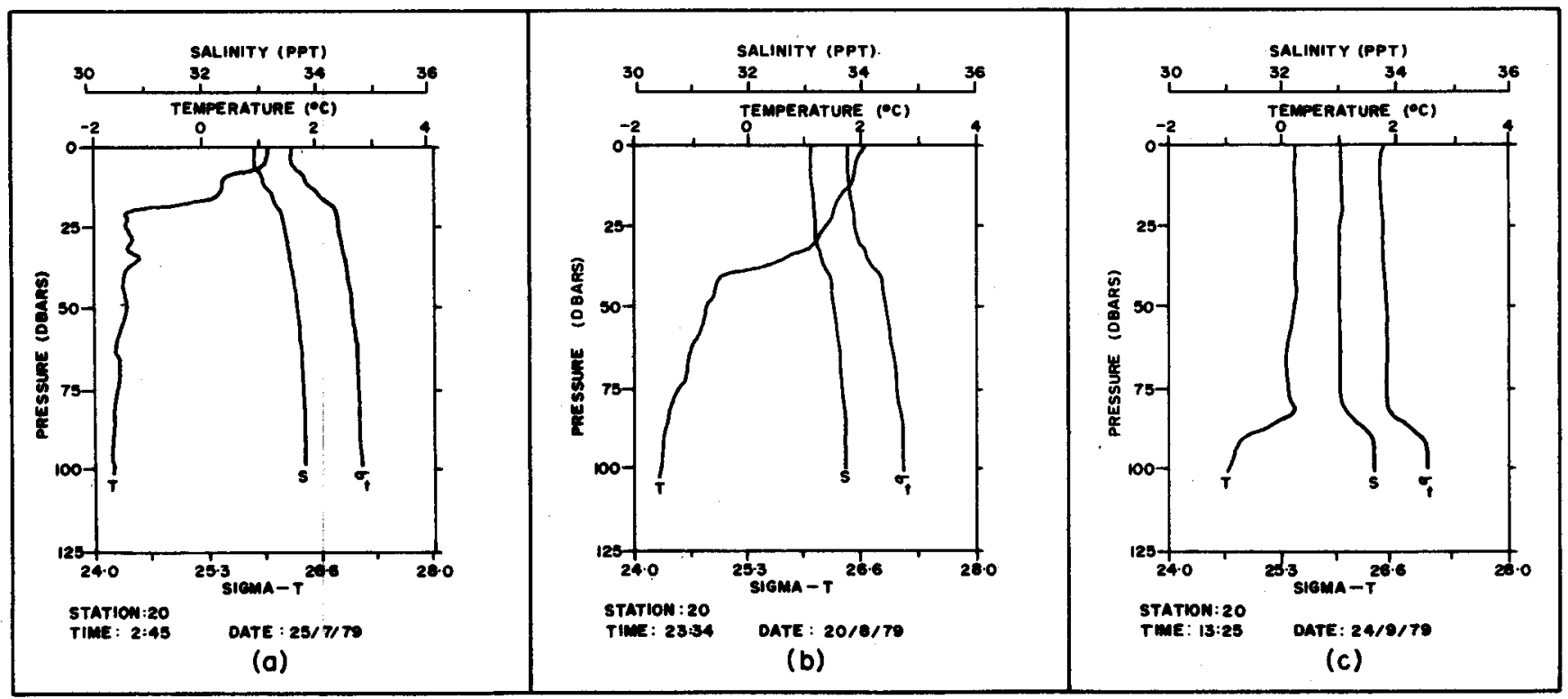

FIG. 7. Successive temperature, salinity and sigma-t profiles at offshore station 20 (30 km east of Devon Island), in 1979 . (Pressure in dbars is approximately equal to depth in metres.) 


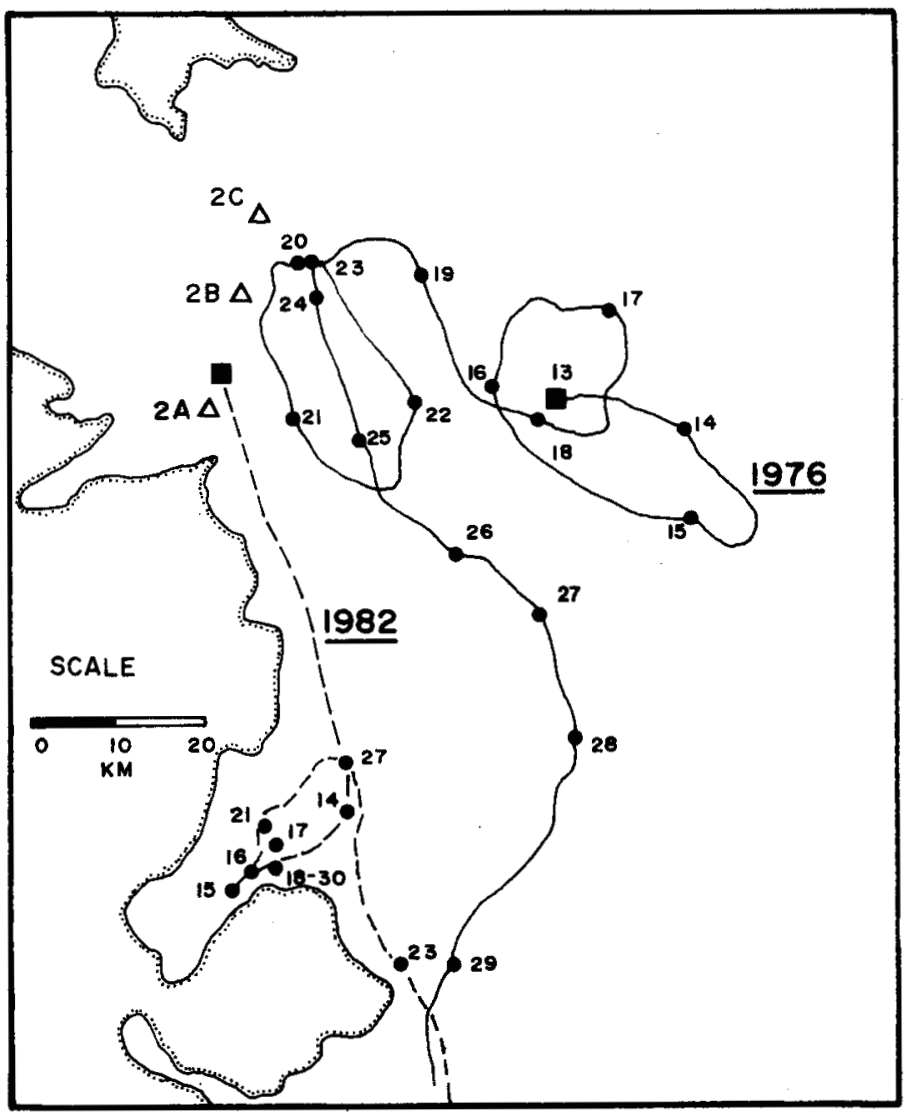

FIG. 8. Tracks of two drifters, 1976 and 1982, moving in the approaches to Lady Ann Strait east of Devon Island during August 1979. The triangles mark the locations of CTD stations in Lady Ann Strait. The squares indicate the release points of the drifters, and the dots show the first reported position on the day whose date appears beside it. One of the tracks is shown as a dashed line for clarity.

Further offshore, surface flows were more variable in direction (see drifter 1976, Fig. 8), although the net flow was southwesterly. Offshore surface baroclinic flows (relative to $300 \mathrm{~m}$ ) had magnitudes of 3 to $5 \mathrm{~cm} / \mathrm{s}$ (Fig. 9). The $35 \mathrm{~m}$ current meters at moorings $A$ and $B$ (Fig. 9) both indicated southwesterly flows averaging about $5 \mathrm{~cm} / \mathrm{s}$. The low frequency flows were variable, however, with amplitudes reaching $20 \mathrm{~cm} / \mathrm{s}$ at $35 \mathrm{~m}$ depth. Reversals occurred more frequently at greater depths.

Along the coast to the east of Devon Island, the pattern of flow was to the south and southwest becoming more concentrated as it passed Philpots Island (Fig. 9). The concentration of flow along the Devon Island coast was also readily apparent in the data provided by the satellitetracked drifters. Figure 10 is a plot showing vector velocities of all 1979 drifters which crossed the latitude of $75^{\circ} 58^{\prime} \mathrm{N}$. The plot depicts a strong flow between about 8 to $35 \mathrm{~km}$ offshore, with typical current speeds of about $40 \mathrm{~cm} / \mathrm{s}$ and a maximum value of $58 \mathrm{~cm} / \mathrm{s}$. Offshore of this strong current, the flow was weaker and more likely to be directed to the northwest and west. Circulation in the coastal areas immediately to the north and south of Philpots Island was relatively stagnant, and drifters which entered these regions often took several days to exit and rejoin the main coastal flow.

The dynamic topographies in Figure 9 all show a largescale meander or eddy on the outside edge of the current, east of Philpots Island. It was centred approximately $70 \mathrm{~km}$ east of Devon Island and had a diameter of approximately $50 \mathrm{~km}$. Mooring $\mathrm{E}$ was in the region where the meander(s) rejoined the main southerly flow. The mean flow recorded here was to the northwest, in agreement with the dynamic height plots. Two drifters travelling northwest past site $\mathrm{E}$, then made counterclockwise turns and entered the main southerly flow (Fissel $e t$ al., 1980). If a northwesterly flow at mooring $\mathrm{E}$ is indicative of the same meander, then it was present during most of August and September 1979. It is possible that this meander may be influenced by the local topography, because it is situated over a relatively shallow bank, east of the trench which runs south from the mouth of Lady Ann Strait.

In 1979, three moorings ( $C, D$ and $E$ ) were placed at the same latitude in order to measure lateral variations in the Baffin Current to the east of Philpots Island (Fig. 10). The

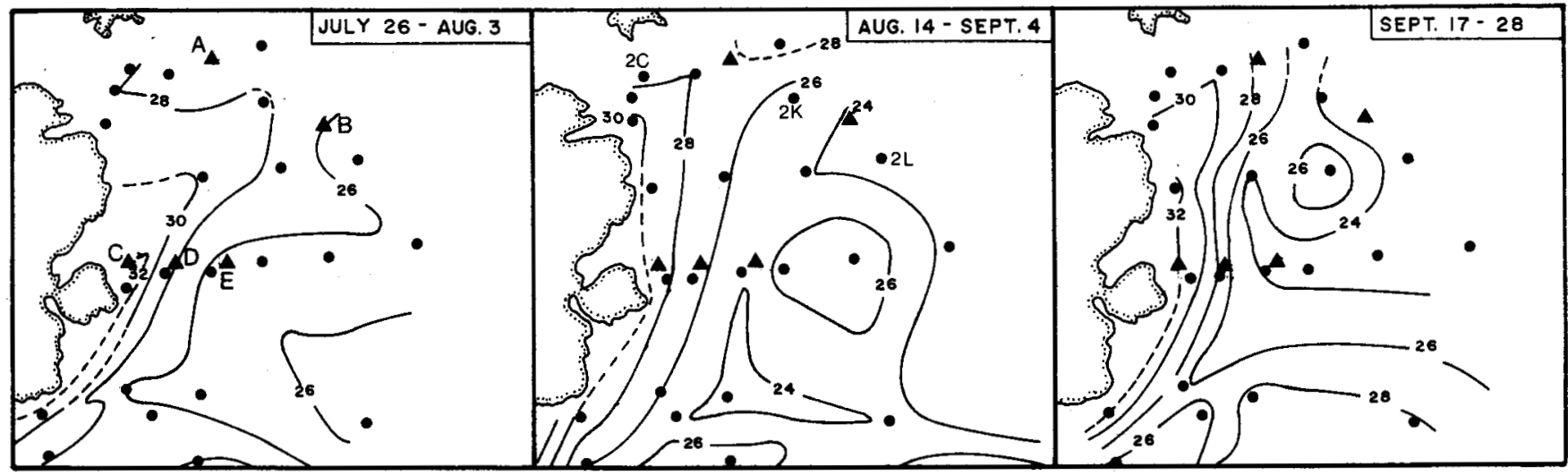

FIG. 9. The surface dynamic height anomaly east of Devon Island (in dynamic $\mathrm{cm}$ ) relative to 300 dbar for three periods of CTD observations in the summer of 1979. The dots mark the CTD stations used to compile the chart. The triangles mark the locations of current meter moorings in the area. (Numbers and letters [e.g. 2L] beside dots, and letters beside triangles are station names). The indicated baroclinic surface flow is parallel to the contour lines, with greater dynamic heights to the right of the flow. The current speed is inversely proportional to the spacing between the contours. 
flow recorded at mooring $\mathrm{D}$ was quite strong and steady southerly at all three depths of 35,125 and $250 \mathrm{~m}$. The average vector velocity at $35 \mathrm{~m}$ at mooring $D$ was $17.5 \mathrm{~cm} / \mathrm{s}$ towards $205^{\circ}$, with a mean speed of $20 \mathrm{~cm} / \mathrm{s}$. The flow at mooring $\mathrm{D}$ is coherent with depth but is reduced to an average velocity of $5 \mathrm{~cm} / \mathrm{s}$ at $250 \mathrm{~m}$ and is slightly more westerly at $218^{\circ}$. Apparently mooring $\mathrm{D}$ was usually not in the strongest part of the current. However, at times, speeds up to $40 \mathrm{~cm} / \mathrm{s}$ were recorded at the $35 \mathrm{~m}$ level at this site suggesting the possibility of occasional shifts in the position of or an overall increase in the current magnitude.

Mooring E (Fig. 10) was in the area where dynamic topography and drifter motion suggested a return of the meander to the main southerly flow. The flow at $35 \mathrm{~m}$ here during the summer of 1979 had a vector average velocity of $2.2 \mathrm{~cm} / \mathrm{s}$ at $327^{\circ}$ but mean speeds averaged $9.8 \mathrm{~cm} / \mathrm{s}$, with a maximum recorded speed of $36 \mathrm{~cm} / \mathrm{s}$. No $125 \mathrm{~m}$ record exists and only a short record (10 days) for $250 \mathrm{~m}$ was recovered, but this showed northerly flow as well. These data suggest that the eastern edge of the Baffin Current off Philpots Island was between moorings $\mathrm{D}$ and $\mathrm{E}$, or approximately $35 \mathrm{~km}$ offshore. This agrees with the drifter results shown in Figure 10.

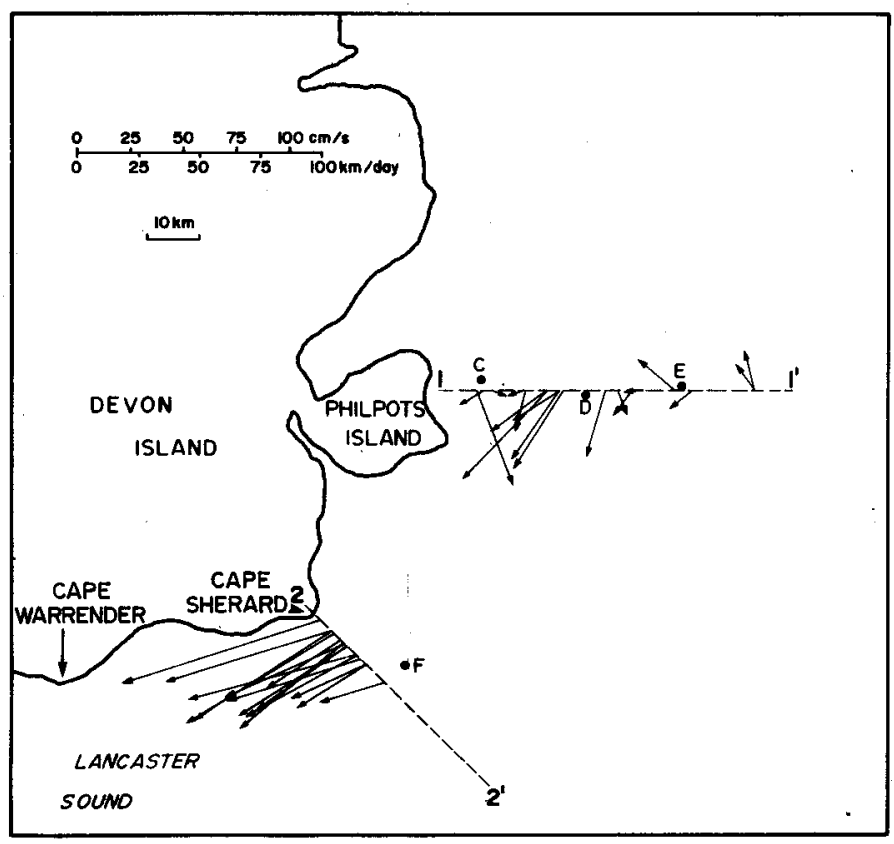

FIG. 10. Velocities of near-surface currents measured by satellitetracked drifters crossing two sections off Devon Island in 1979. Letters indicate current meter mooring locations.

Mooring $\mathrm{C}$ was roughly $10 \mathrm{~km}$ offshore of Philpots Island and the drifter data (Fig. 10) indicate that it was inshore of the main flow. The vector average velocity at $35 \mathrm{~m}$ was $18 \mathrm{~cm} / \mathrm{s}$ at $210^{\circ}$, and the mean speed of $24 \mathrm{~cm} / \mathrm{s}$ was less than the speed of the drifters passing with the main current between moorings $C$ and $D$. The current is coherent in speed and direction at the three different measurement depths of mooring $\mathrm{C}$, with speeds decreasing with

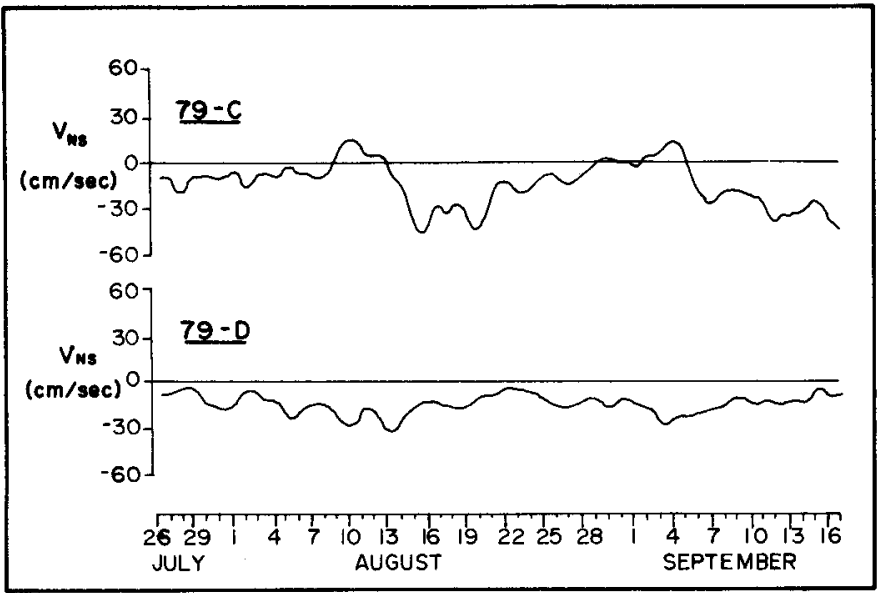

FIG. 11. Low pass filtered northerly component of velocity at $35 \mathrm{~m}$ depth, stations $C$ and D. (Locations shown in Figure 10.)

distance from the surface. Low frequency clockwiserotating flow reversals occurred twice with periods of four and five days, and extended to at least $250 \mathrm{~m}$ depth. During the second reversal, southerly-moving drifters passed within $6 \mathrm{~km}$ of mooring $\mathrm{C}$ but showed no resemblance to the flow measured at $C$. During the reversals at $C$, the flow at mooring D increased (see the N-S components, Fig. 11); a cross correlation of the two $35 \mathrm{~m}$ low frequency $\mathrm{N}-\mathrm{S}$ components shows a significant negative correlation (Fig. 12). On two occasions, as the southerly flow at mooring $D$ increased, the southerly flow at mooring $\mathrm{C}$ decreased and became northerly. The best correlation occurred with the $\mathrm{C}$ record leading $\mathrm{D}$ by three to four days. While the flows at the two moorings are clearly related, the physics of the correlation remains to be determined.

The current follows the east coast of Devon Island flowing southwesterly around Cape Sherard and into Lancaster Sound. All the drifters released off Philpots Island in 1979 passed within $20 \mathrm{~km}$ of Cape Sherard (Fig. 10). The fastest drifters reached speeds of $100 \mathrm{~cm} / \mathrm{s}$ and

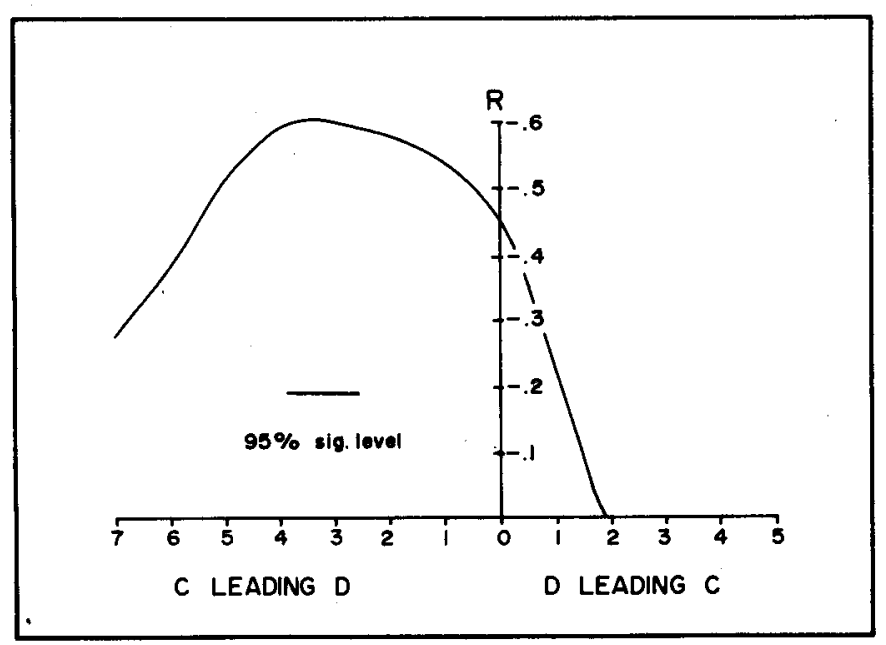

FIG. 12. Cross-correlation coefficient $(R)$ versus time lag in days for northerly velocity components measured at stations $C$ and $D, 35 \mathrm{~m}$ depth. (Locations shown in Figure 10.) 
passed within $5 \mathrm{~km}$ of Cape Sherard. Further offshore, drifters moved slower; for example at $18 \mathrm{~km}$ offshore, speeds were reduced to $32 \mathrm{~cm} / \mathrm{s}$.

Data collected during the summer of 1978 were less extensive than those obtained during 1979 , but the same general patterns of flow were indicated. The reader is referred to Fissel et al. (1980) for more detail.

\section{Conditions in Eastern Lancaster Sound}

After passing Cape Sherard, the Baffin Current penetrates westward along the north side of Lancaster Sound, crosses to the south side of the sound and then flows out to the east. This intrusive flow is the dominant circulation feature of eastern Lancaster Sound. The intrusive current pattern was clearly indicated in the paths of nearly all of the 18 satellite-tracked drifters (Fig. 13) which were released in the summer of 1979 at various locations within $60 \mathrm{~km}$ of the east coast of Devon Island. Of these eighteen drifters, all but one followed the intrusive current into eastern Lancaster Sound. (The one exception was deployed offshore of the Baffin Current in the Central Disordered Zone, discussed below). Of the 17 drifters which entered Lancaster Sound from Baffin Bay, 13 returned to Baffin Bay from the

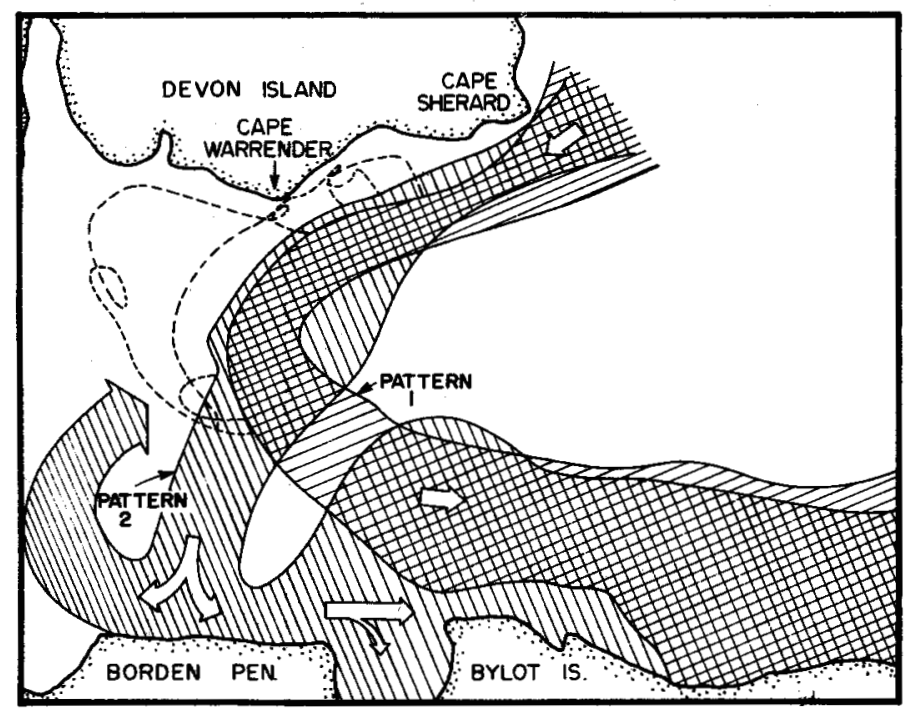

FIG. 13. Envelopes containing drifter tracks obtained in 1979 in eastern Lancaster Sound, divided according to two patterns. Shown separately as dashed lines are the tracks of four drifters which departed from the major flow patterns.

southern side of Lancaster Sound, two exited into Navy Board Inlet and two failed within eastern Lancaster Sound.
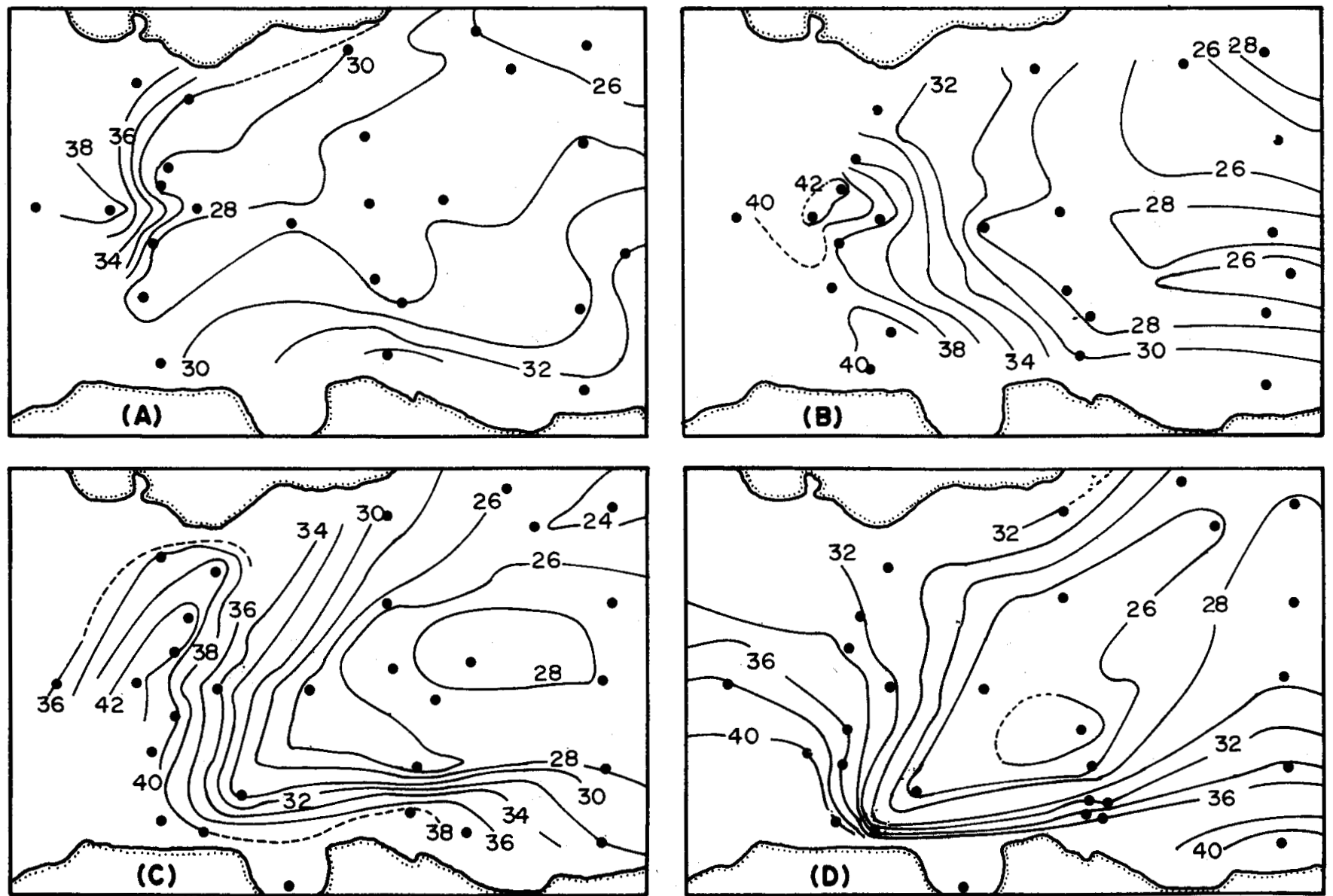

FIG. 14. Surface dynamic height anomalies (in dynamic $\mathrm{cm}$ ) relative to 300 dbar level for four periods of CTD observations in 1979: (A) July 18-19 (B) July 29-Aug. 3 (C) Sept. 2-4 and (D) Sept. 14-23 in eastern Lancaster Sound. (The dots mark the station locations). The indicated surface flow is parallel to the contour lines, with greater dynamic heights to the right of the flow. Current speed is inversely proportional to the spacing between the contours. 
Portions of four of these drifter tracks deviate from the common pathways of most of the other drifters, as indicated in Figure 13. Three of these departures from the usual patterns occurred in the vicinity of Cape Warrender, Devon Island. The paths of these drifters apparently reflect smaller scale nearshore circulation features and are not representative of the larger scale offshore circulation patterns. The remaining deviation from the envelopes of drifter tracks occurred in mid-sound, late in September. By this time, large amounts of new sea ice had formed which may account for the anomalous track.

During the crossing of Lancaster Sound, the drifter tracks divide into two alternative patterns (Fig. 13). Of the sixteen drifters released in 1979 which remained operational on crossing the sound approximately half (nine) followed a southeastward course (pattern 1) as they passed through the middle of the sound. These drifters then proceeded out of Lancaster Sound returning to Baffin Bay well offshore of the northwestern tip of Bylot Island. The remaining seven drifters continued to follow a southwestward course travelling to within $15 \mathrm{~km}$ of Borden Peninsula (pattern 2).

Their subsequent movements indicated a complex circulation pattern north of the peninsula. Approximately half of these drifters (four) turned eastwards and left Lancaster Sound (one via Navy Board Inlet). The remaining three drifters followed the coastline west to the mouth of Admiralty Inlet and then turned north. While one drifter failed at this point, the remaining two continued to turn clockwise, crossing their original tracks at the centre of the sound. They then exited from the sound to the southeast into either Baffin Bay or Navy Board Inlet.

Further evidence of the two patterns of the intrusive current is provided in the maps of surface dynamic height anomalies, relative to a 300 dbar reference level, computed from the 1979 CTD data (Fig. 14). On 18-19 July the mid-sound flow had a southwesterly tendency, heading towards the western end of Borden Peninsula. Later, in early August, the streamlines show a southeasterly set towards northwestern Bylot Island. For the last two sets of CTD observations (2-4 September and 14-23 September), the mid-sound flow was directed towards central Borden Peninsula whereupon the flow turned abruptly to the east. In terms of the two patterns derived from the 1979 drifter data, the first, third and fourth sets of CTD-derived circulation patterns follow pattern 2 (southwesterly) while the second set follows pattern 1 (southeasterly).

The drifter and CTD data obtained in the summer of 1978 indicate that the intrusive current was clearly present during the period of observations (Fissel et al., 1980). Because of the lower quality of the data (due to less accurate and less frequent recording of drifter positions, and larger separations between CTD stations) it was not possible to distinguish between the two patterns of the intrusive current crossing the sound. On one occasion, 19-21 September 1978 , the dynamic height computations indicated that the intrusive current had penetrated further into the sound

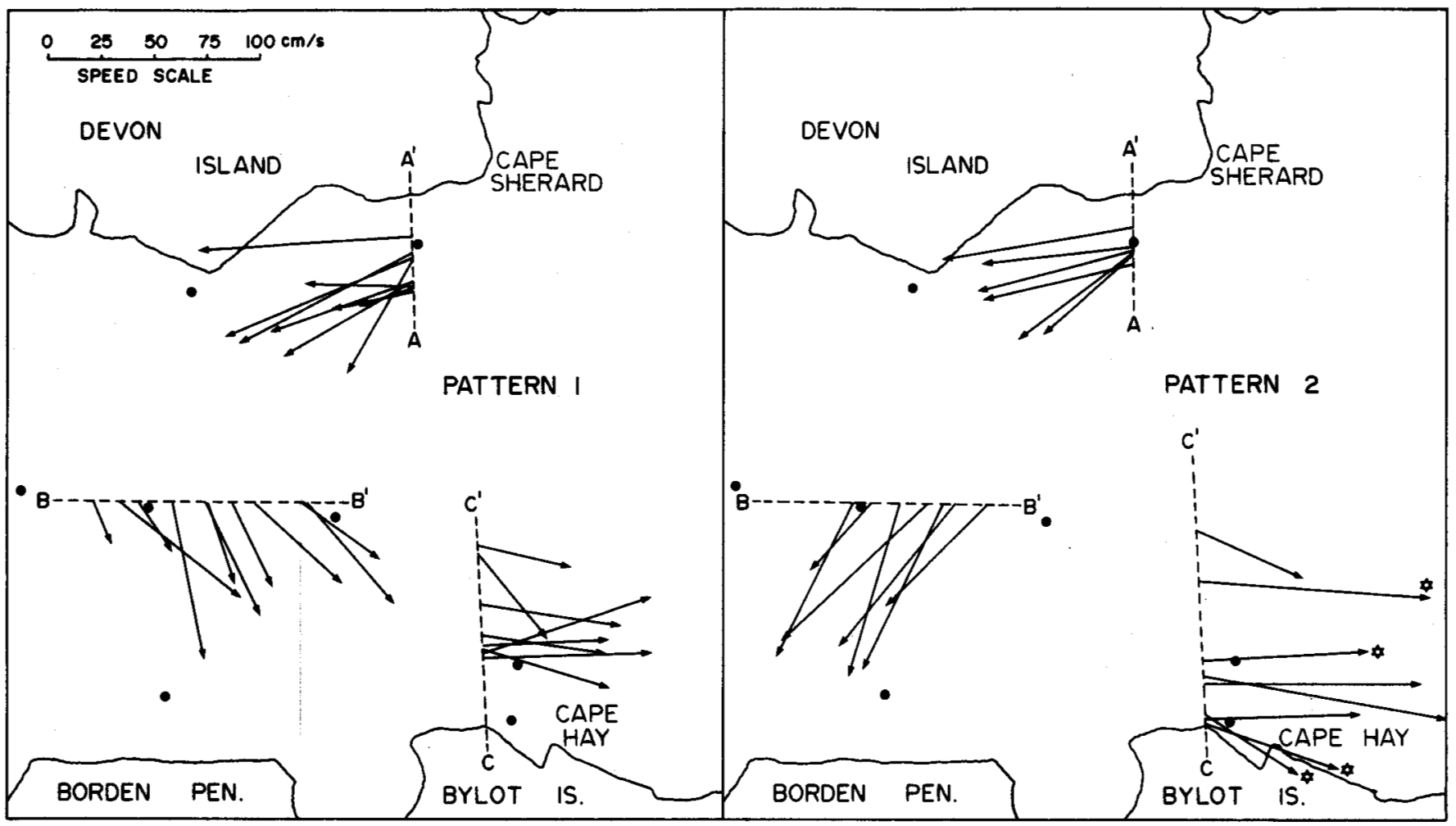

FIG. 15. Near-surface current velocities measured by satellite-tracked drifters through three cross-sections of the intrusive current. The velocities are presented separately for each pattern of the current. The symbol $\left(^{*}\right)$ represents velocities of drifters deployed in western and central Lancaster Sound. The dots mark the locations of current meter moorings. 
than on any other occasion. At this time, the current streamlines extended along an east-west axis to the westward limit of the CTD stations, some $70 \mathrm{~km}$ west of the line joining Cape Sherard and Cape Hay. The penetration of the intrusive current was between 25 and $75 \mathrm{~km}$ west of this line during all other observation periods in 1978 and 1979.

To provide a more quantitative description of the intrusive current, the 1979 drifter velocities were computed at three cross-sections (A-A', B-B' C-C') as shown in Figure 15. To the southwest of Cape Sherard $\left(A-A^{\prime}\right)$ the nearsurface currents were typically $70 \mathrm{~cm} / \mathrm{s}$ in speed and were remarkably uniform in direction with an observed range of only $61^{\circ}$. Another distinctive feature of the flow through this section is the limited width over which the current was observed: all fifteen drifters passed within a band 6 to $16 \mathrm{~km}$ offshore. On crossing the centre of Lancaster Sound (B-B') the flow is more variable in both location and velocity. Drifters crossing from north to south were observed over a $35 \mathrm{~km}$ wide section of the centre of the sound. When southwesterly flows occurred at mid-sound, the current was usually stronger than the southeasterly flows (median value for the seven occurrences is $87 \mathrm{~cm} / \mathrm{s}$ as compared to $54 \mathrm{~cm} / \mathrm{s}$ for the ten occurrences of southeasterly flows).

The drifter movements in the outflow on the southern side of Lancaster Sound east of Navy Board Inlet (C-C') were faster than those observed in the centre and northern sections $\left(A-A^{\prime}\right.$ and $\left.B-B^{\prime}\right)$. Both the median $(81 \mathrm{~cm} / \mathrm{s})$ and maximum $(117 \mathrm{~cm} / \mathrm{s})$ speeds were largest at section $C-C^{\prime}$. Drifter passages through the section occurred over a range of $33 \mathrm{~km}$ with the most southerly being within $4 \mathrm{~km}$ of the shoreline. For drifters which followed the mid-sound southeasterly pattern, there was a distinct tendency to remain further offshore (at section $\mathrm{C}^{-} \mathrm{C}^{\prime}$ ) passing through the section 11 to $30 \mathrm{~km}$ from the coast. Drifters originating east of Devon Island which followed the mid-sound southwesterly pattern and those drifters which were deployed further to the west in Lancaster Sound passed out of the sound over the full range of $33 \mathrm{~km}$ through section $C-\mathrm{C}^{\prime}$.

A comparison was made between current meter data from a nominal depth of $35 \mathrm{~m}$ and the simultaneous nearsurface velocities measured by drifters passing within $6 \mathrm{~km}$ of the current meter mooring (Fig. 16). The results of the limited number of possible comparisons indicate that the measurements agree remarkably well, in view of the differences of spatial and temporal averaging inherent in the two types of data. The directions agree to within $\pm 25^{\circ}$, while the ratio of current meter to drifter speeds is $0.6 \pm 0.4$. Based on this close agreement, we will make use of the directional data of the uppermost current meters in describing the near-surface circulation. The current meter speed measurements must be used with more caution, bearing in mind the relatively large observed differences.

The directional distribution of currents measured by the uppermost current meters is presented in Figure 17. At mooring sites located in the intrusive current where it

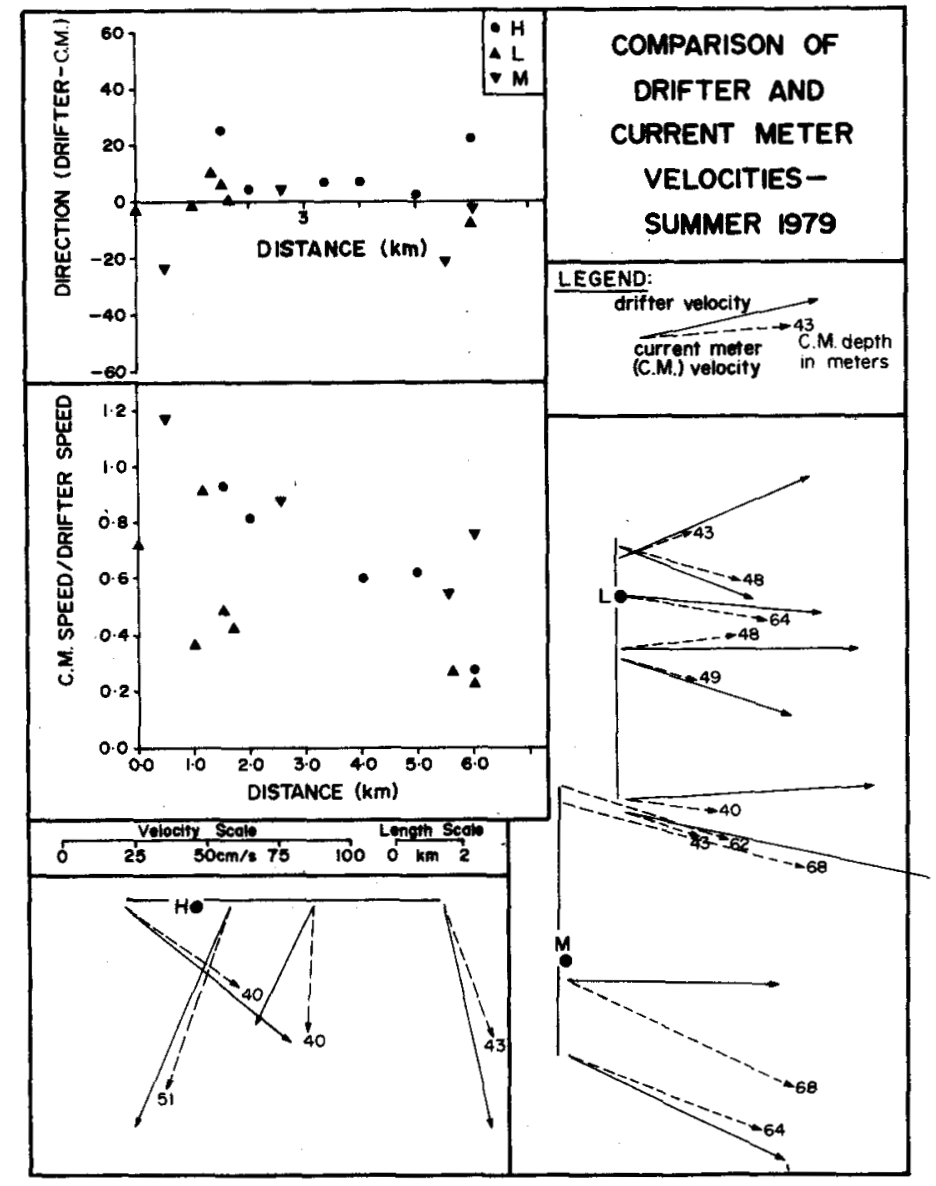

FIG. 16. A comparison of drifter and simultaneous uppermost current meter velocities for separations of $6 \mathrm{~km}$ or less at mooring stations $\mathrm{H}, \mathrm{L}$ and $\mathbf{M}$, located in eastern Lancaster Sound.

flows into and out of Lancaster Sound (stations 1 and 4;6, $\mathrm{L}$ and $\mathrm{M}$ ), the flow was characterized by low directional variability. The site of the steadiest flows in terms of directional variation was station 4 where the observed range of directions was from $223^{\circ}$ to $277^{\circ}$ with $95 \%$ of the measured currents falling within a $36^{\circ}$ range centred on $251^{\circ}$. These results are in good agreement with the description of the near-surface currents based on the drifter data.

On the south side of the sound, the outflowing easterly current was characterized by relatively steady flows, although they are somewhat more variable than those on the north side. At station L, $95 \%$ of the measured directions were between $60^{\circ}$ and $150^{\circ}$, while closer to shore at station $\mathbf{M}$ the directional spread was smaller, ranging from $70^{\circ}$ to $130^{\circ}$ for $95 \%$ of the data. A comparison of the subsurface speeds at the levels of the uppermost current meters located in eastern Lancaster Sound indicates that the speeds of the outflow were more variable than those of the inflowing portion of the current. While the mean speeds were lower, the maximum speeds were larger at stations off the northwest coast of Bylot Island than off the southern coast of Devon Island (Table 1). 


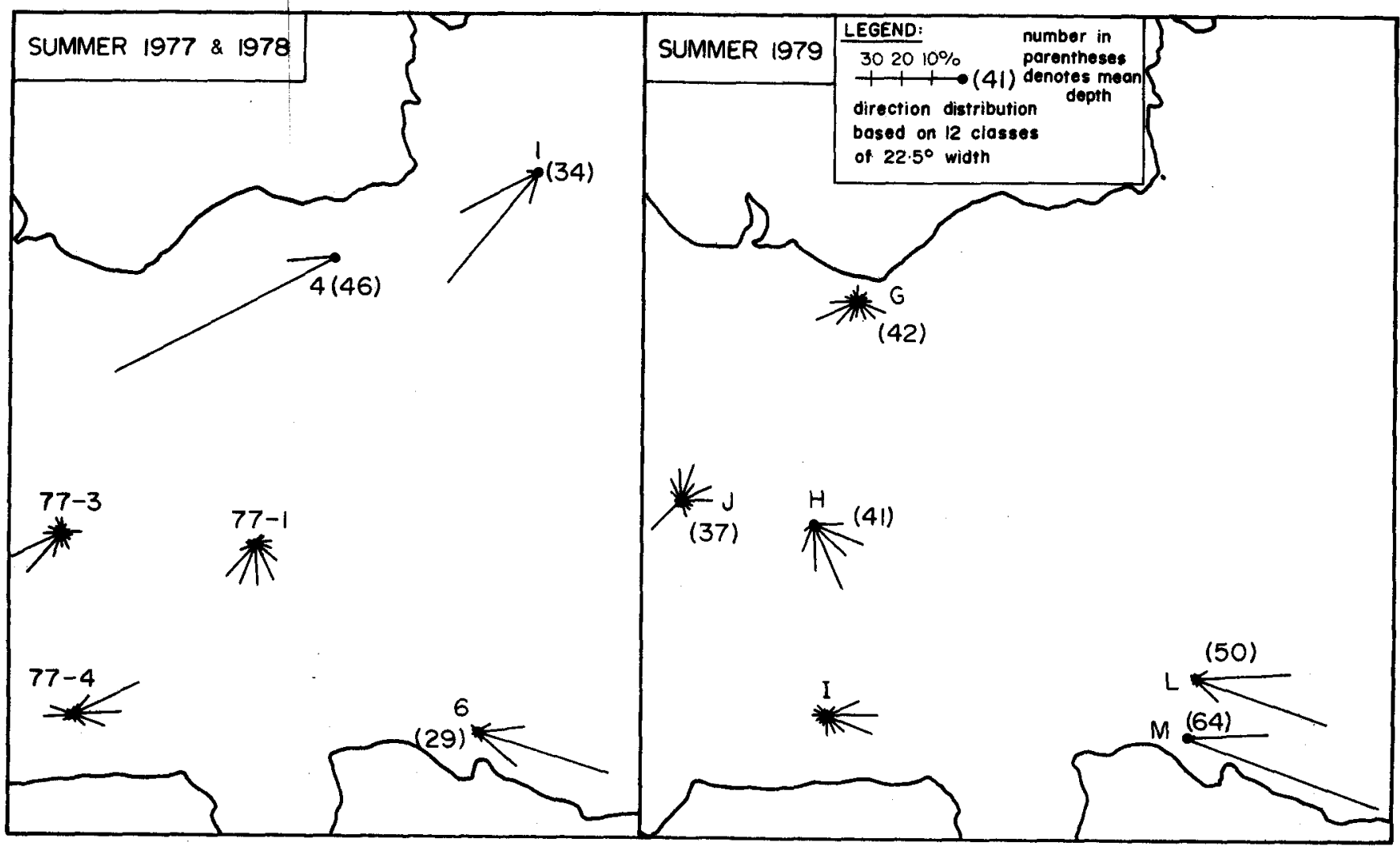

FIG. 17. Directional distributions of currents measured at $35 \mathrm{~m}$ in eastern Lancaster Sound during the summers of 1977 (stations $77-1,77-3$ and 77-4), 1978 (stations 1, 4 and 6) and 1979 (stations G, H, I, J, L and M).

TABLE 1. Summary of current meter measurements from the uppermost current meters at sites located in the intrusive current

\begin{tabular}{|c|c|c|c|c|c|c|c|}
\hline \multirow[b]{2}{*}{ Station } & \multirow{2}{*}{$\begin{array}{l}\text { Record } \\
\text { Length } \\
\text { (days) }\end{array}$} & \multirow{2}{*}{$\begin{array}{c}\text { Mean } \\
\text { Depth } \\
(\mathrm{m})\end{array}$} & \multicolumn{2}{|c|}{ Speed } & \multirow{2}{*}{$\frac{\text { Vector }}{\begin{array}{l}\text { Speed } \\
(\mathrm{cm} / \mathrm{s})\end{array}}$} & \multirow{2}{*}{$\begin{array}{c}\text { Average } \\
\text { Dir. } \\
\left({ }^{\circ} \mathrm{T}\right)\end{array}$} & \multirow{2}{*}{$\begin{array}{c}\text { Steadiness } \\
\text { Factor B } \\
\%\end{array}$} \\
\hline & & & $\begin{array}{c}\text { Mean } \\
(\mathrm{cm} / \mathrm{s})\end{array}$ & $\begin{array}{l}\text { Max. } \\
(\mathrm{cm} / \mathrm{s})\end{array}$ & & & \\
\hline $77-1$ & 60 & (35) & 24.3 & 95.4 & 16.2 & 177 & 67 \\
\hline $77-3$ & 63 & (35) & 37.4 & 111.5 & 19.0 & 233 & 51 \\
\hline 1 & 45 & 35 & 21.4 & 73.7 & 20.3 & 230 & 95 \\
\hline 4 & 20 & 46 & 58.2 & 89.4 & 57.6 & 251 & 99 \\
\hline 6 & 46 & 29 & 50.5 & 104.3 & 45.3 & 110 & 90 \\
\hline 8 & 45 & 83 & 27.0 & 90.0 & 20.6 & 96 & 76 \\
\hline G & 61 & 42 & 21.1 & 78.2 & 6.8 & 208 & 32 \\
\hline H & 52 & 41 & 33.8 & 84.9 & 26.7 & 154 & 79 \\
\hline I & 52 & (35) & 20.6 & 75.1 & 6.6 & 134 & 32 \\
\hline $\mathbf{J}$ & 50 & 37 & 21.5 & 79.6 & 9.0 & 25 & 42 \\
\hline L & 56 & 50 & 36.1 & 86.3 & 34.3 & 105 & 95 \\
\hline $\mathbf{M}$ & 55 & 64 & 52.0 & 104.5 & 51.1 & 105 & 98 \\
\hline
\end{tabular}

Where pressure data are not available, the nominal depth is provided in parentheses. (The steadiness factor is defined as the vector-averaged speed divided by the mean speed times $100 \%$ [Ramster et al., 1978]. For locations where the steadiness factor is $70 \%$ or less, the vectoraveraged mean is not representative of the time series current data.)

From the drifter data, we have seen that the greatest variation in the intrusive current occurs in the course of its crossing Lancaster Sound. The variability is clearly demonstrated in the directional distributions of subsurface currents measured at stations $77-1$ and $77-3$ in the summer of 1977 (Fissel and Wilton, 1978) and at stations $\mathrm{H}$ and $\mathrm{J}$ in the summer of 1979. The mean speeds here were reduced as compared to other portions of the intrusive current but strongflows were occasionally observed; thelargestrecorded subsurface current $(111.5 \mathrm{~cm} / \mathrm{s})$ was measured in 1977 at station 77-3.

Previously, on the basis of drifter data, the intrusive current was described as following two spatial patterns when crossing the sound: the first has velocities directed to the southeast and the second has velocities of south to southwesterly (Fig. 13). Stations 77-3 and H, occupied in 1977 and 1979, respectively, were located within $1.3 \mathrm{~km}$ of each other. Both were within the envelope of southwesterly drifter pathlines and just on the western edge of the southeasterly drifter pathlines. However, the directional distributions measured at these stations are not bimodal but rather indicate a continuum of directions from southwesterly to southeasterly resulting from smaller-scale circulation features, including tidal currents and inertial oscillations. When the major intrusive current is elsewhere, these small-scale circulation features become important in determining the current direction. Nevertheless, the bimodal nature of the intrusive flow can be detected by examining the directional distribution of those current measurements whose speeds are sufficiently large to be identified with the presence of the intrusive current. For example, the directional distribution of currents with speeds greater 


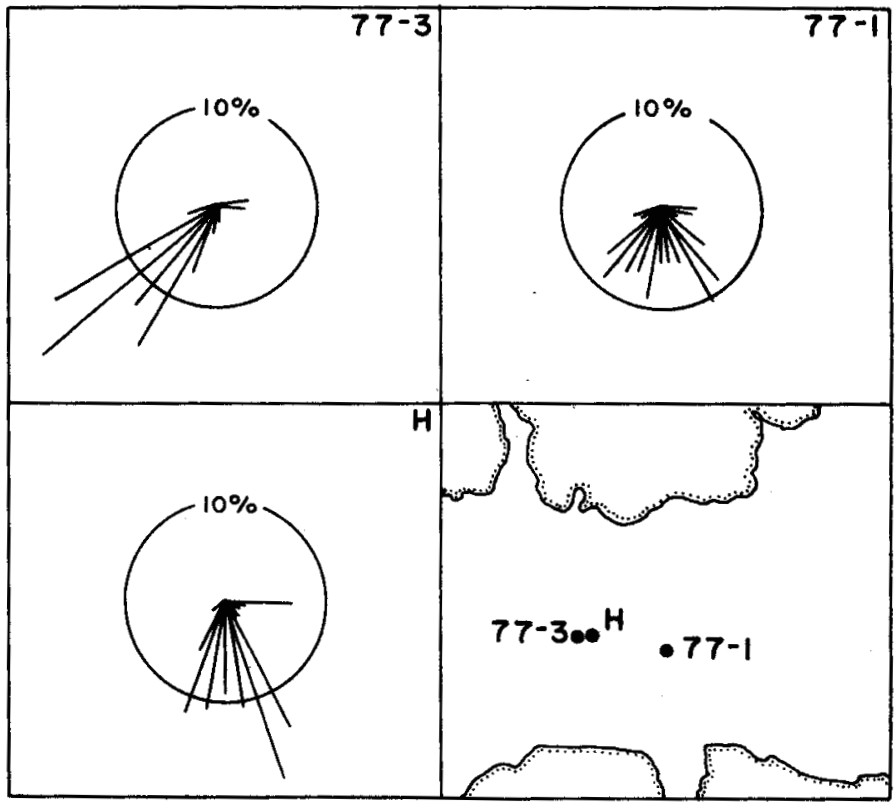

FIG. 18. Direction distributions of currents at $35 \mathrm{~m}$ which exceeded 48 $\mathrm{cm} / \mathrm{s}$ at stations $77-1,77-3$ and $\mathrm{H}$, in eastern Lancaster Sound.

than $48 \mathrm{~cm} / \mathrm{s}$ recorded at station $\mathrm{H}$ in 1979 had two peaks, at $165^{\circ}$ and $205^{\circ}$ (Fig. 18). In the summer of 1977 , no strong southeasterly flows were measured at nearby station 77-3. Because strong southeasterly flows were measured at sta-

(a)

(b) tion 77-1, the southeasterly pattern may have shifted further to the east.

The 1979 observations indicated that the patterns of circulation north of Borden Peninsula were strongly influenced by the state of the intrusive current. When the intrusive current followed pattern 1 (southeasterly at midsound, Fig. 13) simultaneous net easterly flows were observed north of the peninsula at moorings $\mathrm{H}, \mathrm{I}$ and $\mathrm{J}$ (Fig. 3) and in drifter trajectories. On some occasions (10 September; 29 September) easterly flows were presently only in the middle of the sound while at other times ( 16 August; 26 September) a net easterly flow was confined within $30 \mathrm{~km}$ of the Borden Peninsula coastline. On 26 August, easterly flows were observed both at mid-sound and near the Borden Peninsula coastline. (For a more detailed presentation of these data, see Fissel et al., 1980.)

When the intrusive current followed pattern 2 (southwesterly at mid-sound, Fig. 13) it entered the Borden Peninsula region and turned either east or west within $20 \mathrm{~km}$ of shore. On three such occasions $(1,4$ and 20 September 1979) the currents observed in mid-sound to the west of the intrusive current at station $\mathbf{J}$ had strong northerly components. The reason for the northerly flow observed at station $\mathrm{J}$ is not known, although it may represent a northward deflection of the easterly flow observed north of Borden Peninsula under pattern 1 conditions. However, this suggested cause cannot be confirmed with-

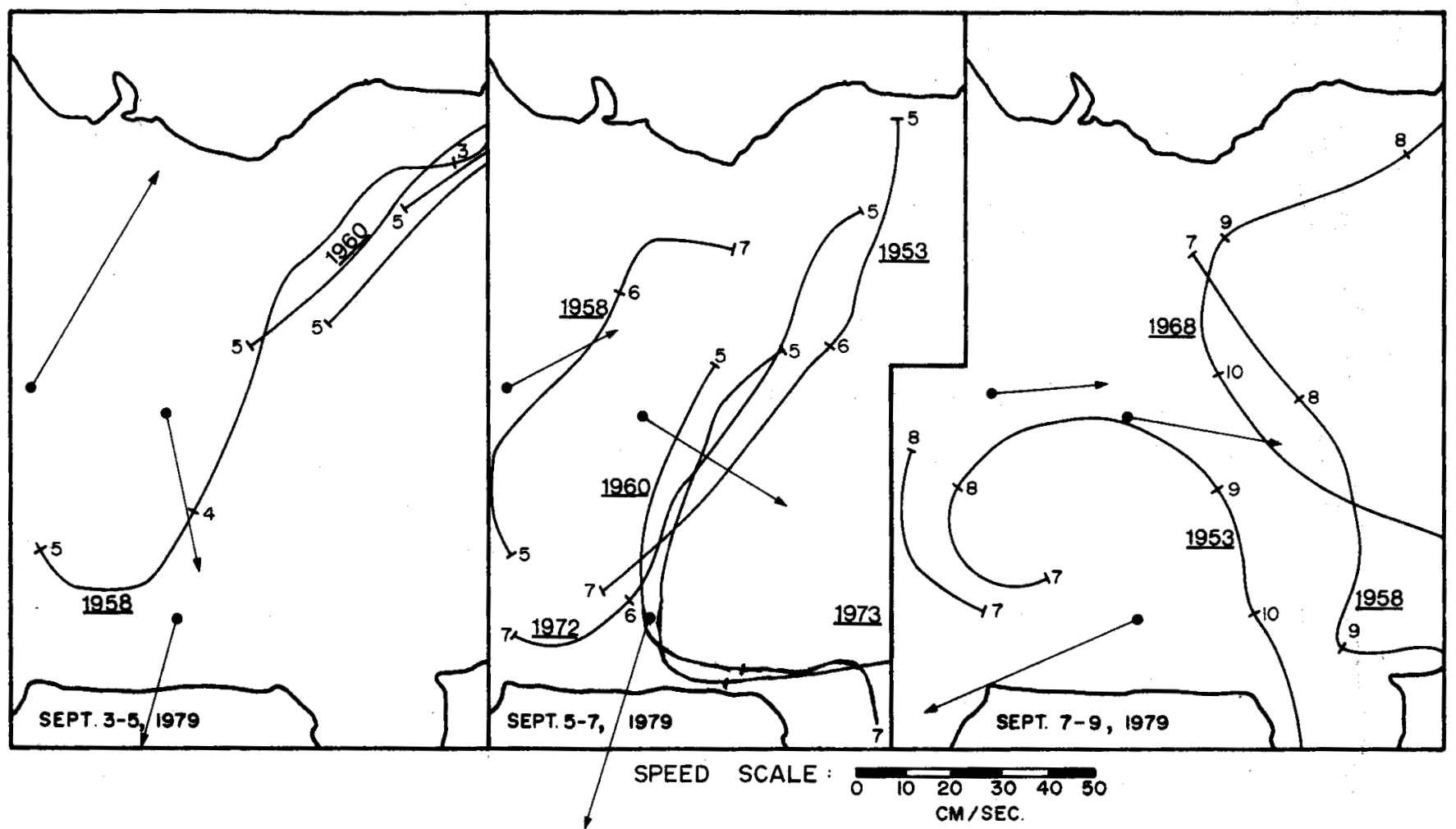

FIG. 19. Case studies in Lancaster Sound of simultaneous drifter and current meter velocities from 3-9 Sept. 1979, illustrating transition from pattern (2) to pattern (1) of intrusive current (see Fig. 13). The underlined numbers (e.g. 1958) are the drifter identity numbers. Each small bar across the drifter tracks denotes the first recorded position on the day whose date appears beside it. The arrows depict the direction and magnitude (measured according to the scale shown) of the daily vector-averaged $35 \mathrm{~m}$ current at each mooring in the area. 
out simultaneous measurements in the intrusive current and further west in Lancaster Sound.

An example of the spatially complex and highly variable circulation patterns off Borden Peninsula is shown in drifter and current meter data obtained between 3 and 9 September 1979 (Fig. 19). For a week or more prior to this period, the intrusive current had been flowing southwesterly at mid-sound, with the currents turning east on approaching Borden Peninsula. On 4 September, one drifter (1958) turned west rather than east. Over the next two days, two other drifters (1953 and 1972) followed the same westerly course while two others (1960 and 1973) turned east (see Fissel, 1980 for complete track plots and listings of the drifter data). The drifters which had moved to the west then turned north and continued to turn, describing an anti-cyclonic loop. Because one drifter (1972) failed on the northward turn, only two loops were described. One (1958) was elongated to the north, having dimensions of 50 by $20 \mathrm{~km}$, and the other was more nearly circular, having a diameter of $25 \mathrm{~km}$. Upon completing the loops both drifters headed south towards Navy Board Inlet with one entering the inlet and the other moving east along the coast of Bylot Island. Following the onset of this anti-cyclonic circulation to the west of the intrusive flow, the currents at mid-sound (stations $\mathrm{H}$ and $\mathrm{J}$ ) rotated so as to be aligned in an easterly direction. Concurrently, the currents at station I off Borden Peninsula veered from southerly to westerly and strengthened. By 8 September, the intrusive current had reverted to the pattern of southeasterly mid-sound flows as indicated by the track of drifter 1968. The sequence of flow patterns observed from 3 to 9 September suggests that the commencement of westerly motion along Borden Peninsula may have been related to the formation of an anti-cyclonic gyre in this area. This event in turn coincided with a change in the pattern of the intrusive current from southwesterly to southeasterly mid-sound flows (pattern 2 to pattern 1).

The intrusion of the Baffin Current into eastern Lancaster Sound appears to be a permanent feature of the summer and early autumn circulation. Data from 1978 and 1979, as well as earlier measurements (see Fissel et al., 1980: section 5.8) are consistent with such circulation patterns. The current is, however, subject to temporal variations in addition to the spatial variations discussed above. The major temporal variation (considering summer and autumn) consists of transitions between flow patterns. While we have identified only two such patterns, gaps in the data allow the possibility of others. In Figure 20, we summarize the pattern of the intrusive current for periods in 1979 when the observational data are sufficient to differentiate between one pattern and the other. The data suggest that the persistence of a given pattern could be as short as two days. The upper bound of persistency could extend to 40 days based on the period from 23 July-30 August during which only southeasterly patterns were observed. It should be noted that southwesterly patterns

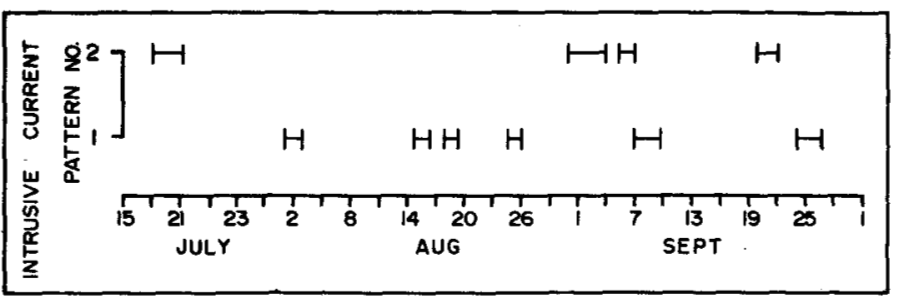

FIG. 20. Patterns of the intrusive current observed in 1979. The bars denote periods during which the current was observed unambiguously to follow pattern 1 or pattern 2 . During the periods between the bars, there were insufficient data to determine the configuration of the flow.

could have occurred in the several data gaps within this period.

The intrusive current spans a considerable range of depths encompassing all of the Arctic Water layer and the upper portion of the Atlantic Water layer. The vertical profile of the average current along the mean flow direction, for the inflowing and outflowing portions of the intrusive current, is displayed in Figure 21. Because the intrusive current appears to have been present at these moorings throughout the period of observation, the mean vertical profile from the current meter data is expected to be representative of the intrusive current itself. For estimates of the range of flows associated with the major current, a low pass digital filter (half-amplitude period of three days) was applied to the time series data to remove diurnal and

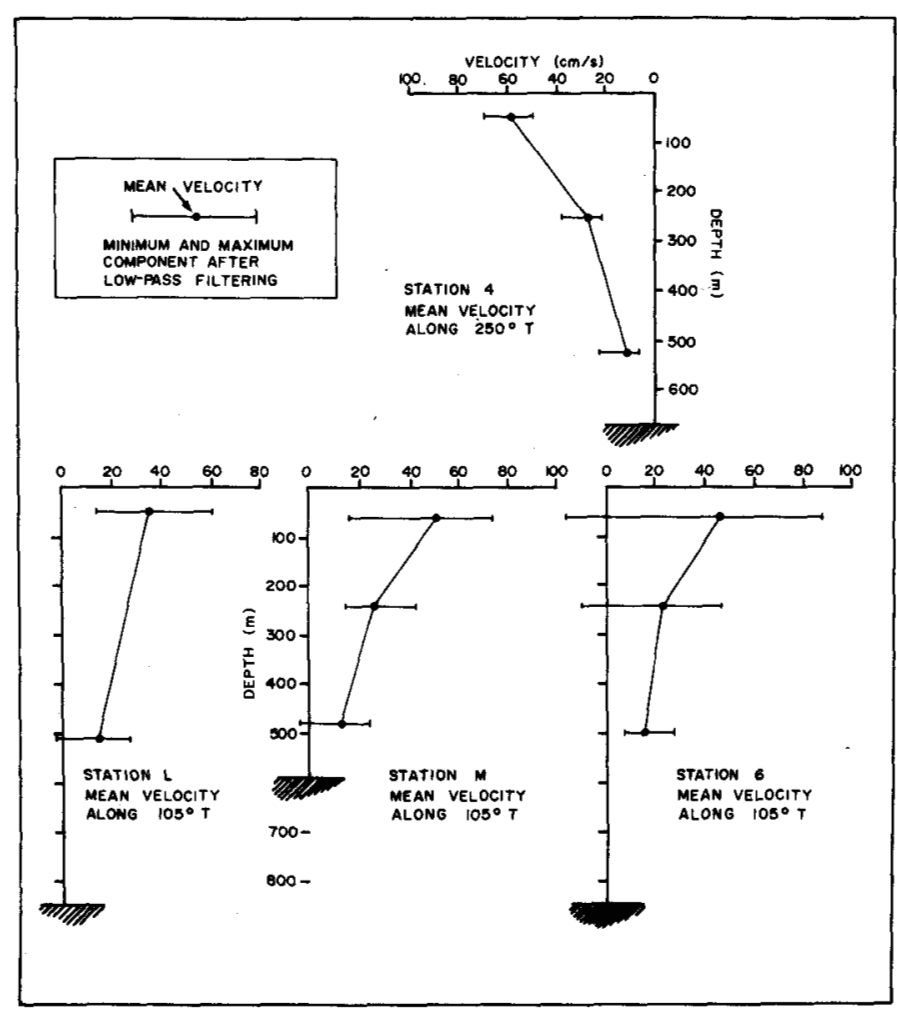

FIG. 21. Average vertical profiles of the intrusive current as measured at mooring stations $4,6, \mathrm{~L}$ and $\mathrm{M}$. The horizontal bars represent the extremes of the current after a low pass filter has been applied to remove daily and higher frequency variations. 
higher frequencies; the minimum and maximum of the component of current along the major axis are also displayed in Figure 21. The vertical profiles clearly show the intrusive current extending to depths of $500 \mathrm{~m}$ for the entire period of observation at station 4 and for most of the time at stations $6, \mathrm{~L}$ and $\mathrm{M}$. In view of the weak stratification measured at depths greater than $500 \mathrm{~m}$, the velocity shear at those depths is expected to be small. The lack of shear combined with the sizeable mean velocities measured at $500 \mathrm{~m}$ depth $(12$ to $16 \mathrm{~cm} / \mathrm{s})$, implies that the intrusive current often extends to the bottom of eastern Lancaster Sound where depths do not exceed $850 \mathrm{~m}$. Consider station $L$, where the current at $500 \mathrm{~m}$ depth averaged $14 \mathrm{~cm} / \mathrm{s}$ (Fig. 21). The geostrophic current profiles computed from CTD casts on 30 July at CTD stations $4 A$ and $4 B$ (locations shown in Fig. 22), adjacent to mooring $L$, indicate that the shear is less than $1 \mathrm{~cm} / \mathrm{s}$ per 100 m over depths from 500 to $700 \mathrm{~m}$. Thus, the current would be expected to extend to the bottom, 700 to $840 \mathrm{~m}$ deep in this particular area.

In the mid-sound portion of the intrusive current, the mean velocities from the current meter data are not truly representative of the mean intrusive current profile due to the wanderings of the flow. However, the intrusive current is clearly evident at nominal depths of 35, 250 and
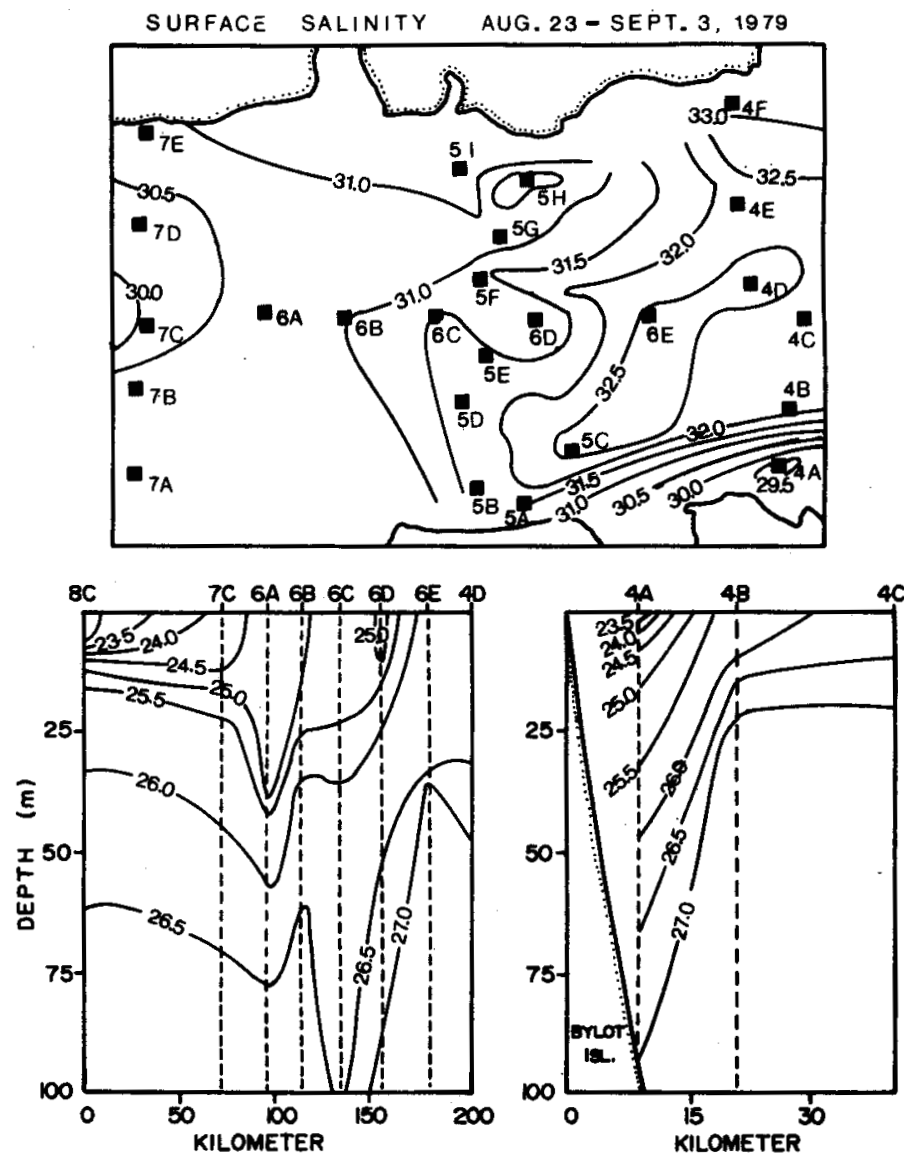

Sections of sigma-t

FIG. 22. Evidence of frontal structures in the intrusive current from CTD data from 23 Aug. - 3 Sept. 1979. The contour interval for surface salinities is $0.5 \%$. The squares mark the station locations.

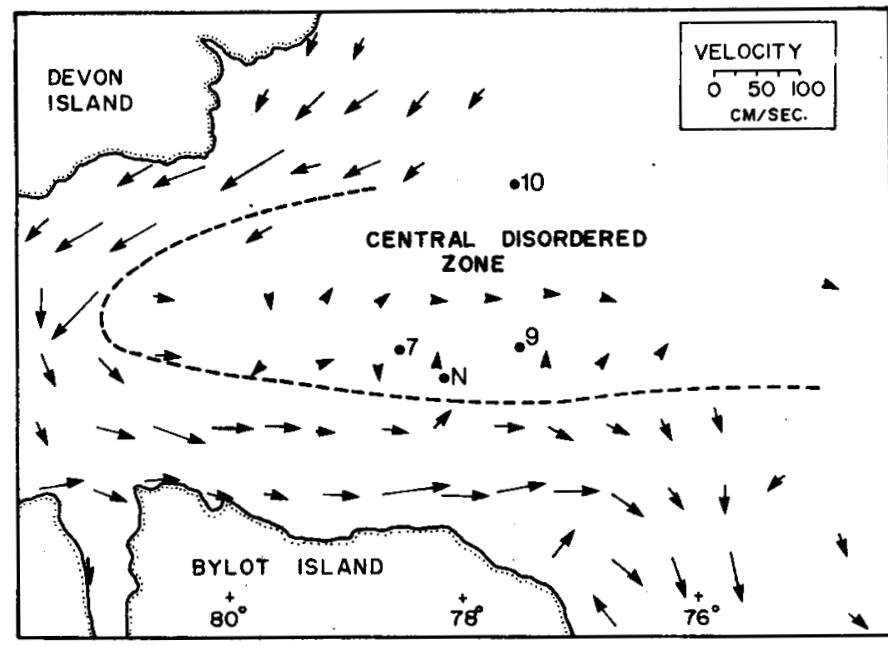

FIG. 23. The vector-averaged velocities for grid areas in the Central Disordered Zone from drifter data obtained in 1979. Each arrow represents the vector-averaged velocity of all the drifters which passed through a grid element with dimensions $0.5^{\circ}$ in longitude by $0.167^{\circ}$ in latitude, centered at the base of the arrow. N, 7, 9 and 10 are the locations of current meter moorings.

$500 \mathrm{~m}$ at station $\mathrm{H}$, both in the strong southerly flows measured at each depth and in the vertical correlations of variations in the current.

CTD data measured along vertical cross-sections through the intrusive current reveal large horizontal density gradients (Fig. 22). The upward-tilting isopycnals associated with the intrusive current reflect an approximate geostrophic balance between the internal pressure gradient and the Coriolis force. Such large horizontal gradients (referred to as fronts) are often associated with a reduction in the vertical density gradient. The reduced stratification of the water column could allow for greater vertical movements in the neighbourhood of the front.

In the area immediately to the east of the intrusive current (which we refer to as the Central Disordered Zone)

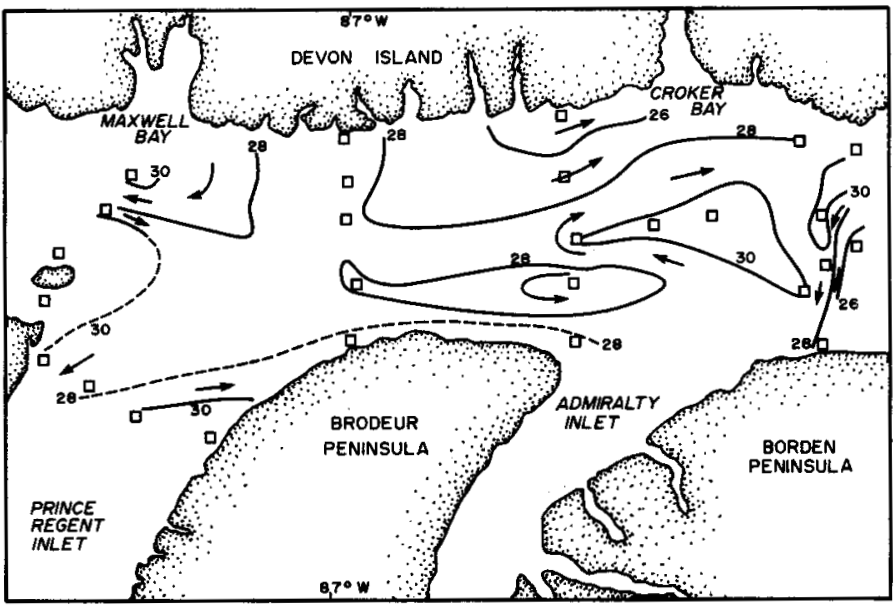

FIG. 24. Dynamic topography (in dynamic $\mathrm{cm}$ ) of the surface relative to $175 \mathrm{dbar}$ for the period 24 Aug. - 6 Sept. 1979 in western Lancaster Sound. The squares mark the station locations and the numbers give the dynamic height anomaly associated with each contour line. The arrows indicate the direction of surface baroclinic flow. Current speed is inversely proportional to the spacing between the contours. 
the near-surface currents are characterized by relatively weak and directionally variable flows. Based on data collected by drogued drifters in summer 1979 , the vectoraveraged surface flows were generally less than $5 \mathrm{~cm} / \mathrm{s}$ (Fig. 23). Little net motion is suggested; however, actual drifter speeds in the zone were often on the order of $15 \mathrm{~cm} / \mathrm{s}$. It is the directional variability which produced the low vector speeds. Although the surface flow was weak and variable, all drifters which did not cease working first exited to the south and east, indicating a net southeasterly drift. The records of the upper current meters (35 m depth, at stations 7, 9, 10 and $\mathrm{N}$ in Fig. 23) indicated average speeds of about $13 \mathrm{~cm} / \mathrm{s}$, with considerable variability in direction.

\section{Conditions in Western and Central Lancaster Sound}

The near-surface circulation in western and central Lancaster Sound differs markedly from that of eastern Lancaster Sound. Previous studies (Bailey, 1957; Collin, 1962;
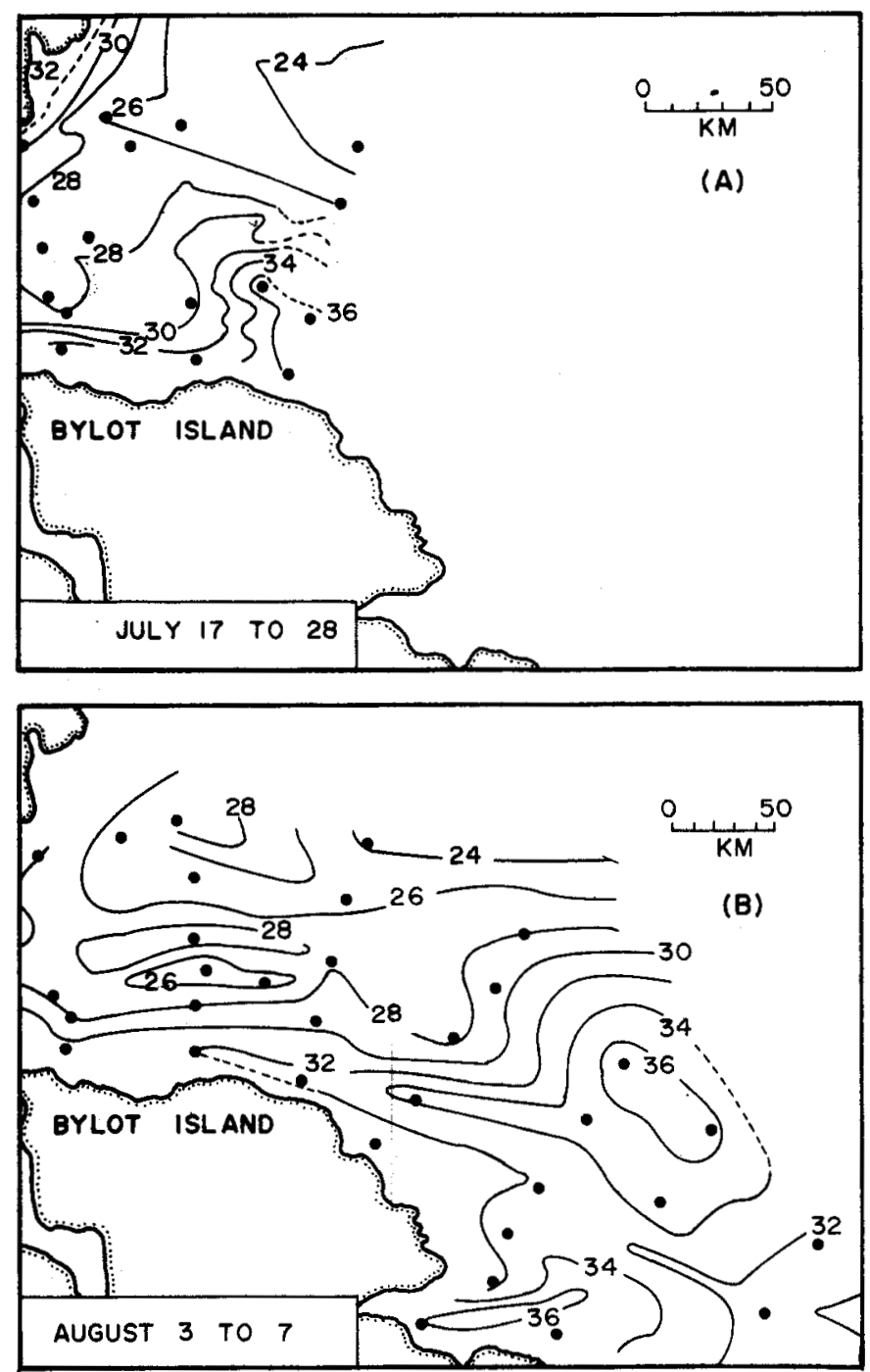

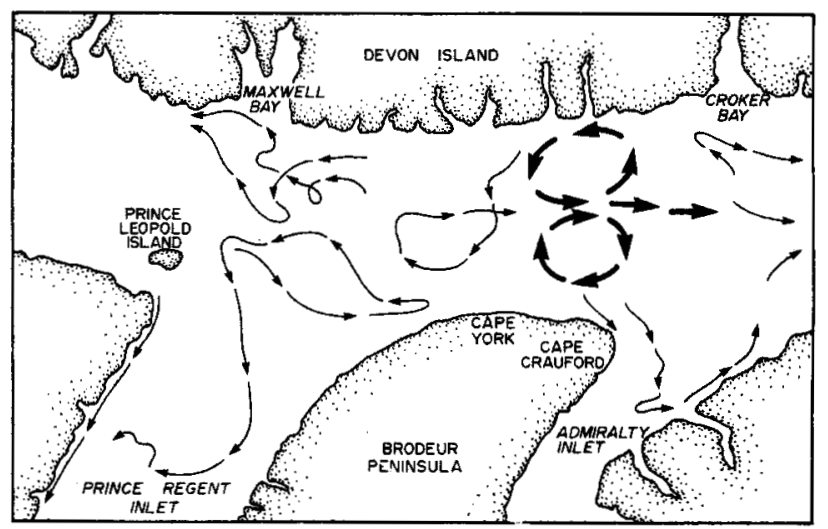

FIG. 25. A schematic presentation of drifter motion during summer 1979 in western and central Lancaster Sound. Representative individual tracks are indicated by thin arrows and patterns suggested by two or more drifters are shown as heavy arrows.

Fissel and Marko, 1978) indicate a complex circulation pattern with both significant eastward and less significant westward flows occurring near the southern and northern
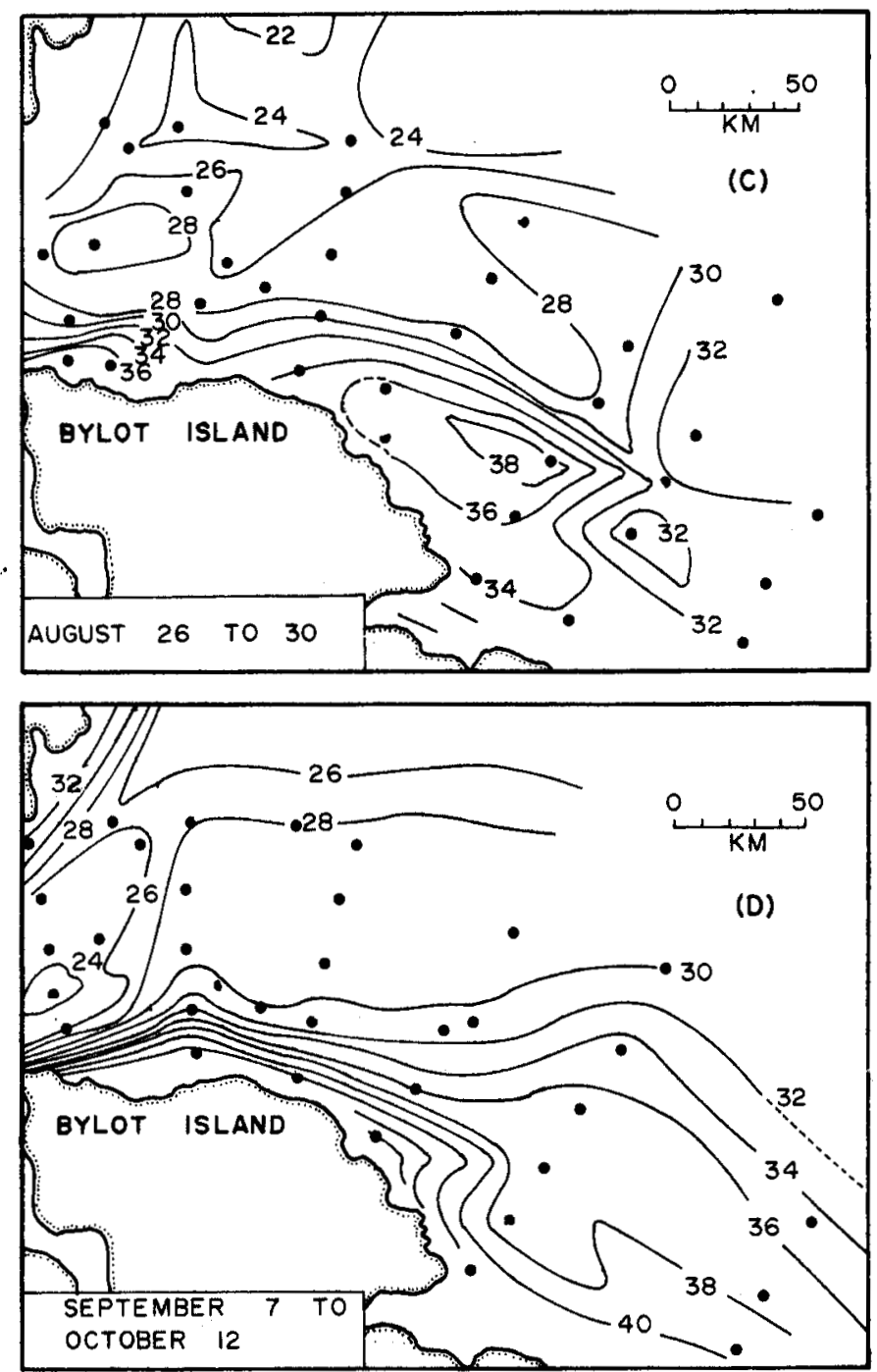

FIG. 26. Dynamic topography (in dynamic $\mathrm{cm}$ ) of the surface relative to $300 \mathrm{dbar}$, for 4 periods in 1979. The dots mark station locations. The indicated surface flow is parallel to the contour lines, with greater dynamic heights to the right of the flow. Current speed is inversely proportional to the spacing between the contours. 
edges of the sound, respectively, as well as transient gyres or eddies in mid-sound.

Figure 24 shows the dynamic topography of the surface relative to $175 \mathrm{dbar}$ for stations occupied between 24 August and 6 September 1979. No continuous eastward flow is apparent in the main channel. A current issuing from Prince Regent Inlet extends along the south side of the sound as far as Admiralty Inlet. Eastward flow is apparent along the north side of the sound, east of $87^{\circ} \mathrm{W}$. Off Maxwell Bay the flow on the north side is to the west, becoming easterly in mid-channel.

In the summer of 1979, a total of 14 drifters was released in central and western Lancaster Sound. In Figure 25, the drifter trajectories are presented schematically. Persistent westerly displacements were observed only in the region off Maxwell Bay. Two drifters entered Prince Regent Inlet from the west, following paths similar to the intrusive currents previously observed by Collin (1962) and Fissel and Marko (1978). Both easterly and westerly motions were observed off the mouth of Prince Regent Inlet. Drifters in the area north of Cape Crauford exhibited eddy-like motion. There was a tendency for cyclonic loops to occur on the north side of the sound, separated by a persistent band of easterly flow from anti-cyclonic loops on the south side. One drifter followed an intrusive pattern in the mouth of Admiralty Inlet.

Both the dynamic topography (Fig. 24) and the drifter data (Fig. 25) indicate a disordered flow field over all of western and central Lancaster Sound. However, except for the area immediately south of Maxwell Bay, there does seem to be a net eastward drift. Of the ten drifters which did not run aground within Lancaster Sound, six exited to the east, two exited to the west and two went into Prince Regent Inlet.

\section{Conditions East of Bylot Island}

The Baffin Current leaves Lancaster Sound along the north coast of Bylot Island. Between Cape Liverpool and the mouth of Pond Inlet, it frequently loses its character as a strong coastal flow, and detaches itself from the northeast corner of the island. Eddies and countercurrents are often observed along the east coast of Bylot Island. Largescale eddies were observed there in 1960 and 1966 (Muench, 1971). The station spacings in those years were not sufficiently dense to define eddies whose scales were less than $50 \mathrm{~km}$.

Figure 26 shows the dynamic topography of the surface relative to $300 \mathrm{dbars}$ for four periods during the summer of 1979. In all cases, the flow appears to move further offshore as it travels along the east coast of the island. This tendency may be due to the broadening of the continental shelf east of the island, which increases from less than $1 \mathrm{~km}$ width near Cape Liverpool to $24 \mathrm{~km}$ width at the southern tip of the island. The large-scale meanders and eddies (usually located near the southern end of the island) are apparently quite frequent, as they appear in three of the four parts of Figure 26.

Drifters passing through this zone exhibited similar largescale patterns. Southeastward velocities between 30 and $75 \mathrm{~cm} / \mathrm{s}$ were observed, with groups of drifters passing at varying distances from the coast. The drifters occasionally described large (up to $70 \mathrm{~km}$ ) meanders and eddies, which led to periods of northerly drift (see Fig. 26b and

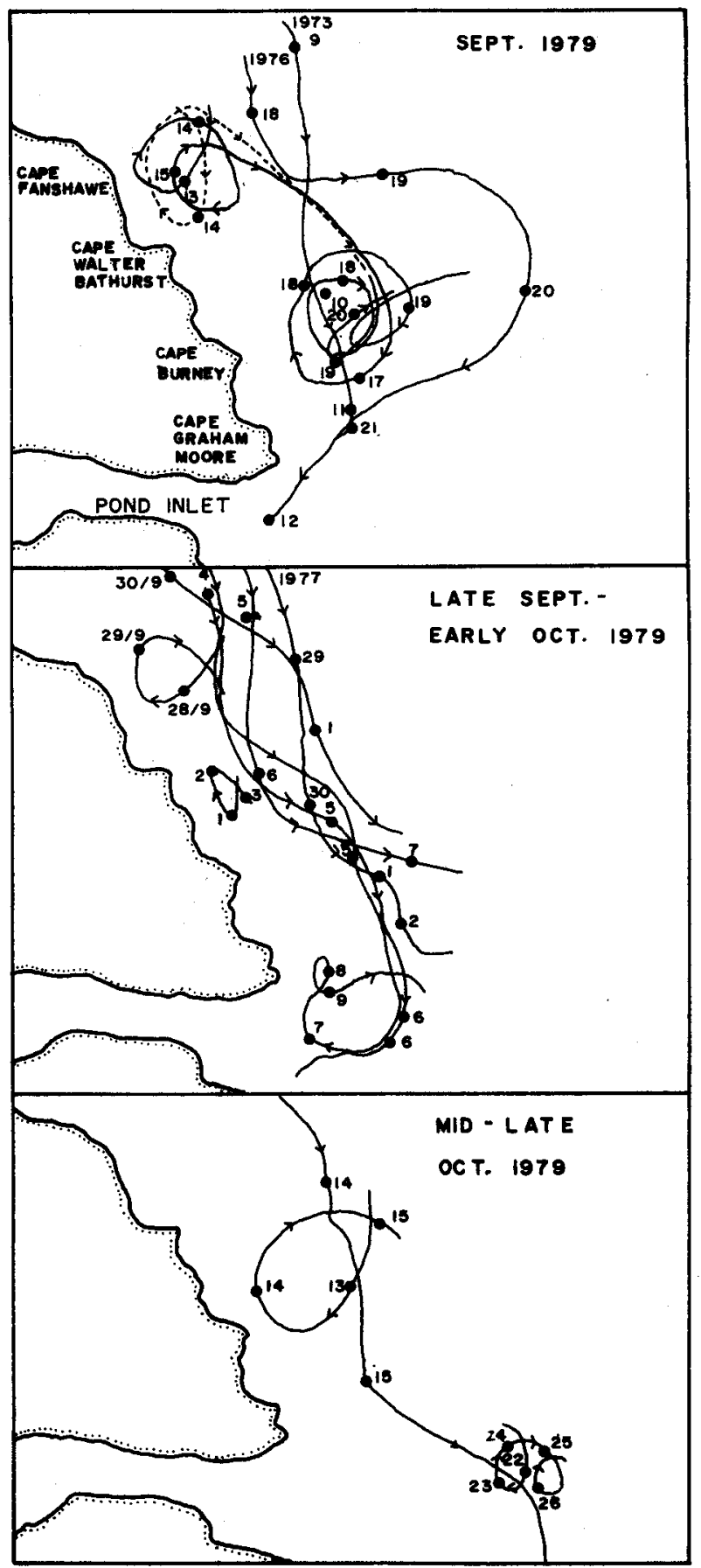

(a)

(b)

FIG. 27. Eddies detected in 1979 by drifter tracks east of Bylot Island: (a) Sept. 9-21 (b) Sept. 27-Oct. 9 and (c) Oct. 13-26. (One track in part (a) has been shown dashed for clarity). Each dot on the tracks denotes the first recorded position on the day whose date appears beside it. 
TABLE 2. Characteristics of eddies observed east of Bylot Island in 1979

\begin{tabular}{|c|c|c|c|c|c|c|c|}
\hline Drifter & Date & Sense & $\begin{array}{c}\text { Approx. Position } \\
\text { of centre } \\
\text { (lat.,long.) }\end{array}$ & $\begin{array}{c}\text { Diameter } \\
(\mathrm{km})\end{array}$ & $\begin{array}{c}\text { Ave. Speed } \\
\text { of drifter } \\
\text { (km/day) } \\
\text { computed } \\
\text { from } \\
\text { successive } \\
\text { positions }\end{array}$ & $\begin{array}{l}\text { Distance } \\
\text { offshore } \\
(\mathrm{km})\end{array}$ & (h) \\
\hline \multirow[t]{3}{*}{1958} & 13-15 Sept & anticyclonic & $73.519,76.784$ & $23 \pm 3$ & $47 \pm 8$ & 17 & $35 \pm 1$ \\
\hline & 16-18 Sept & anticyclonic & $73.194,75.532$ & $18 \pm 1$ & $24 \pm 9$ & 25 & $57 \pm 1$ \\
\hline & 18-20 Sept & anticyclonic & $73.194,75.532$ & $11 \pm 6$ & $19 \pm 9$ & 25 & $48 \pm 1$ \\
\hline \multirow[t]{2}{*}{1959} & 28-29 Sept & anticyclonic & $73.566,76.863$ & $15 \pm 1$ & $29 \pm 12$ & 16 & $42 \pm 1$ \\
\hline & $1-20 \mathrm{Ot}$ & anticyclonic & $73.290,74.448$ & $10 \pm 5$ & $15 \pm 5$ & 10 & $56 \pm 1$ \\
\hline \multirow[t]{2}{*}{1962} & $11-130 \mathrm{ct}$ & cyclonic & $73.473,74.528$ & $8 \pm 2$ & $10 \pm 3$ & 75 & $52 \pm 1$ \\
\hline & $16-19$ Oct & cyclonic & $73.753,75.311$ & $10 \pm 1$ & $11 \pm 9$ & 65 & $78 \pm 3$ \\
\hline 1963 & 6-10 Oct & anticyclonic & $72.808,75.492$ & $22 \pm 1$ & $22 \pm 3$ & 23 & $92 \pm 5$ \\
\hline \multirow[t]{4}{*}{1968} & 13-14 Sept & anticyclonic & $73.556,76.799$ & $17 \pm 3$ & $40 \pm 20$ & 17 & $34 \pm 1$ \\
\hline & 14-15 Sept & anticyclonic & $73.481,76.162$ & $16 \pm 2$ & $36 \pm 6$ & 20 & $31 \pm 1$ \\
\hline & 16-18 Sept & anticyclonic & $73.229,75.514$ & $28 \pm 2$ & $43 \pm 11$ & 28 & $26 \pm 1$ \\
\hline & $19-20 \mathrm{Sept}$ & anticyclonic & $73.191,75.305$ & $12 \pm 5$ & $24 \pm 9$ & 32 & $44 \pm 1$ \\
\hline \multirow[t]{3}{*}{1980} & 13-15 Oct & anticyclonic & $73.252,75.862$ & $29 \pm 4$ & $39 \pm 18$ & 25 & $55 \pm 2$ \\
\hline & $22-23$ Oct & anticyclonic & $72.790,74.447$ & $11 \pm 2$ & $14 \pm 4$ & 53 & $74 \pm 2$ \\
\hline & 25-27 Oct & anticyclonic & $72.778,74.153$ & $9 \pm 1$ & $14 \pm 4$ & 63 & $48 \pm 1$ \\
\hline 1982 & $11-13$ Oct & cyclonic & $73.506,74.518$ & $7 \pm 1$ & $9 \pm 6$ & 75 & $57 \pm 2$ \\
\hline 1983 & $2-3$ Oct & cyclonic & $73.262,75.019$ & $7 \pm 1$ & $12 \pm 5$ & 75 & $42 \pm 2$ \\
\hline
\end{tabular}

Fissel et al., 1980). An intrusive flow at the mouth of Pond Inlet was seen on several occasions.

In addition to the large-scale gyres and meanders in the flow east of Bylot Island, smaller-scale eddies were often observed in drifter tracks, superimposed on the net flow. These eddies were observed from time to time between the main axis of the southeastward flow off the Bylot Island coast and the coast itself (Fig. 27). A total of 16 eddies of varying sizes, locations, and senses of rotation were observed in the tracks of eight drifters released in 1979. They are summarized in Table 2 . Another eight drifters passed through the area without exhibiting any eddy-like motion. Of these, six were tracked between September 13 and October 15, a period which encompasses all of the observations of eddy-like features in the drifter tracks obtained in 1979.

Examination of Table 2 reveals that the observed eddies divide naturally into two classes: anticyclonic eddies within $35 \mathrm{~km}$ of the Bylot Island coast, and eddies more than $50 \mathrm{~km}$ offshore which may have either sense of rotation. The 11 anticyclonic eddies detected in the coastal band had a mean diameter of $18 \pm 7 \mathrm{~km}$, and a mean period of $46 \pm 15 \mathrm{~h}$. Offshore there were four cyclonic and two anticyclonic eddies. The cyclonic eddies had a mean diameter of $8 \pm 1 \mathrm{~km}$ and a mean period of $57 \pm 15 \mathrm{~h}$; the two anticyclonic eddies had a mean diameter of $14 \pm 2 \mathrm{~km}$ and a mean period of $61 \pm 18 \mathrm{~h}$.
The nearshore, anticyclonic eddies appeared to arise more frequently in two locations: one off Cape Fanshawe, the other off Cape Burney. Observations of drifters which passed sequentially through the area of eddies off Cape Burney indicated that the lifetime of an eddy at that location was less than two weeks (Fissel et al., 1980).

Similar patterns were observed in the drift of icebergs tracked from the Cape Fanshawe radar camp in 1978(Riggs et al., 1980). The icebergs described loops, always in an anticyclonic sense, centeredabout $25 \mathrm{~km}$ offCape Fanshawe. Their typical diameters and periods were reported to be either $22 \mathrm{~km}$ and $60 \mathrm{~h}$ or $8 \mathrm{~km}$ and $30 \mathrm{~h}$. The loops were observed intermittently throughout the summer, but more frequently during the first three weeks of August. While the relative importance of the forces controlling iceberg drift is not fully understood, these observations provide supporting evidence for the existence of anticyclonic, nearshore eddies east of Bylot Island.

\section{Conditions East of Baffin Island}

The western boundary of Baffin Bay is characterized by a shallow $(<200 \mathrm{~m})$ continental shelf, extending as far as $50 \mathrm{~km}$ offshore. Beyond the shelf is the continental slope, where the water depths increase from $200 \mathrm{~m}$ to $2000 \mathrm{~m}$ over distances of typically $50 \mathrm{~km}$. This slope region forms the western boundary of a deep (1800-2400 m) and relatively flat basin (see Fig. 1). The continental shelf is cut by deep underwater canyons extending from the inlets of Baffin Island. Pond Inlet is the most northerly of these features, which also occur off Buchan Gulf, Scott Inlet and the fiords which open into Home Bay.

Five drifters were tracked down the Baffin Island coast in 1978 , and twelve passed through the area in 1979. Nearsurface currents as measured by the drifters tracked in the summer of 1979 are presented in Figure 28. The southeasterly flows associated with the Baffin Current dominate the circulation. The magnitude of the near-surface currents changes significantly as a function of distance from the coast; the strongest flows occurred over the steep portion of the continental slope while velocities were generally lower over the continental shelf. For example, off Cape Adair the average velocities over the shelf ranged from 12 to $24 \mathrm{~cm} / \mathrm{s}$, compared with 24 to $40 \mathrm{~cm} / \mathrm{s}$ over the slope. However, sampling was more frequent over the shelf break because of the tendency of the drifters to follow this route; this resulted in fewer data for the shallow shelf regions.

The baroclinic surface circulation was determined from the surface dynamic topography relative to $300 \mathrm{dbar}$ (Fig. 29). The deduced currents are stronger over the inshore portion of the continental slope which tends to be considerably steeper than the adjacent offshore regions. This circumstance is evident to varying degrees in every crosssection of CTD stations (perpendicular to the coast) between the mouth of Pond Inlet and Cape Dyer. 


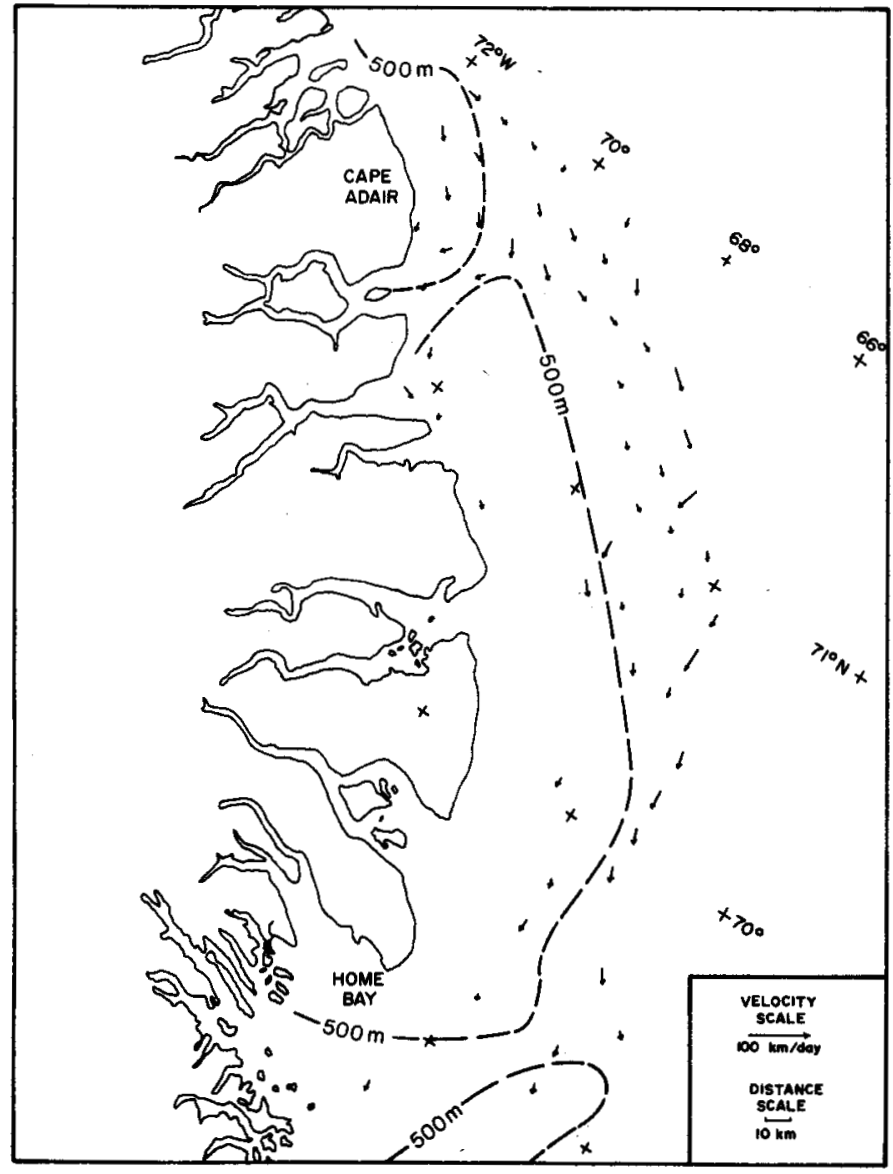

FIG. 28. Average velocities from drifter data obtained in 1979 off the east coast of Baffin Island. Each arrow represents the vector-averaged velocity of all the drifters which passed through the grid square, centered at the base of the arrow. The grid elements have dimensions of $0.5^{\circ}$ longitude and $0.167^{\circ}$ latitude. Only arrows representing three or more averages are included.

The weaker outer portion of the Baffin Current appears to meander between adjacent cross-sections as indicated in the shapes of the 30 and 32 dynamic $\mathrm{cm}$ contours of dynamic height anomaly (Fig. 29). Scale lengths of 60-100 km along the stream and $35-40 \mathrm{~km}$ across the stream are suggested for this phenomenon on the basis of the dynamic height contours. However, because the apparent alongstream scale length is comparable to the spacing of the CTD sections, the meanders may not be adequately resolved and the actual scale-lengths may be shorter than the above estimates. Further evidence of meander-like features is provided in the tracks of several drifters which followed offshore trajectories in water depths exceeding $1000 \mathrm{~m}$. The meander-like features in each track vary considerably as to location, shape and scale, with the latter ranging from 40 to $120 \mathrm{~km}$.

Four current meter moorings from 1978 and two from 1979 provide time series current data, useful in delineating the temporal variations of the circulation. The 1978 moorings were located in pairs off Cape Jameson and Cape Adair (Fig. 30). Station 11 was located on the shelf, $10 \mathrm{~km}$ from its outer edge, while station 13 was located on the slope offshore of the steepest zone. Stations 14, 15, R and $Q$ were all located on the continental slope off Cape Adair with station 14 only $2 \mathrm{~km}$ past the shelf edge.

The vector-averaged velocities at all current meter stations were to the southeast, aligned within 20 degrees of the direction of the local bathymetry (Fig. 30). While the strongest net flows were observed over the continental slope (Fig. 30 and Table 3), occasional peak speeds of up to $85 \mathrm{~cm} / \mathrm{s}$ were measured at locations over the shelf; these exceeded any speed measurements obtained over the slope.

The directional distributions reveal steadier flows at stations 14 and 15 (located on the slope) than at stations 11 and 13 (on the shelf and offshore of the steepest portion of the slope, respectively). Following removal of the tidal, inertial and higher frequency variations by means of a low pass digital filter (half of the amplitude passed at a period of three days), no reversals were found in the $35 \mathrm{~m}$ currents at stations 14 and 15 . The same procedure applied to the data from stations 11 and 13 revealed one period of reversed flows with a duration of three days or more at station 11 and two such reversals at station 13. At all sites, the temporal variations of the uppermost current meter data were characterized by synoptic variations over a wide range of time scales from three days to several tens of days.
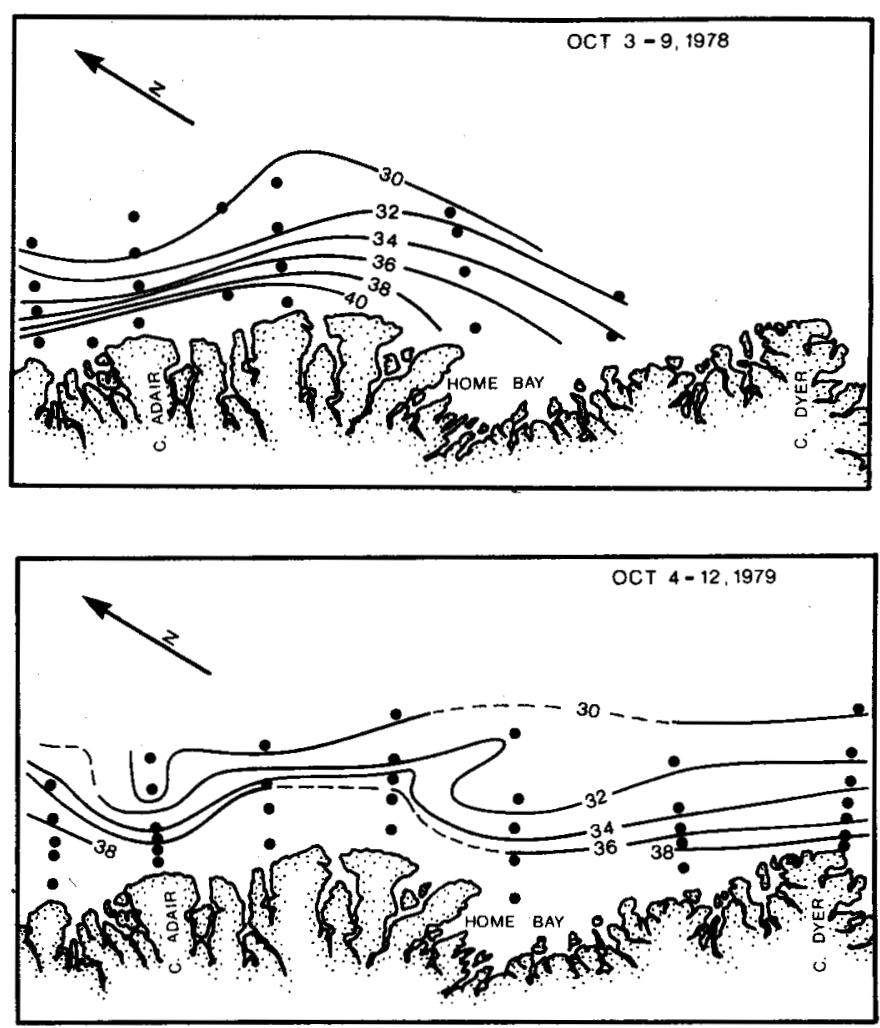

FIG. 29. Dynamic topography (in dynamic $\mathrm{cm}$ ) of the surface relative to 300 dbar from CTD data collected in 1978 and 1979 off the east coast of Baffin Island. The dots mark the station locations. The indicated surface flow is parallel to the contour lines, with greater dynamic heights to the right of the flow. Current speed is inversely proportional to the spacing between the contours. 
Based on the current meter data, the Baffin Current appears to extend from the surface to depths of at least $500 \mathrm{~m}$. At station 15 and nearby station $\mathrm{R}$ (operational in 1978 and 1979, respectively), a steady southeasterly flow was measured at $500 \mathrm{~m}$. At station 13, the speed signal failed on the current meter at $750 \mathrm{~m}$ depth during the

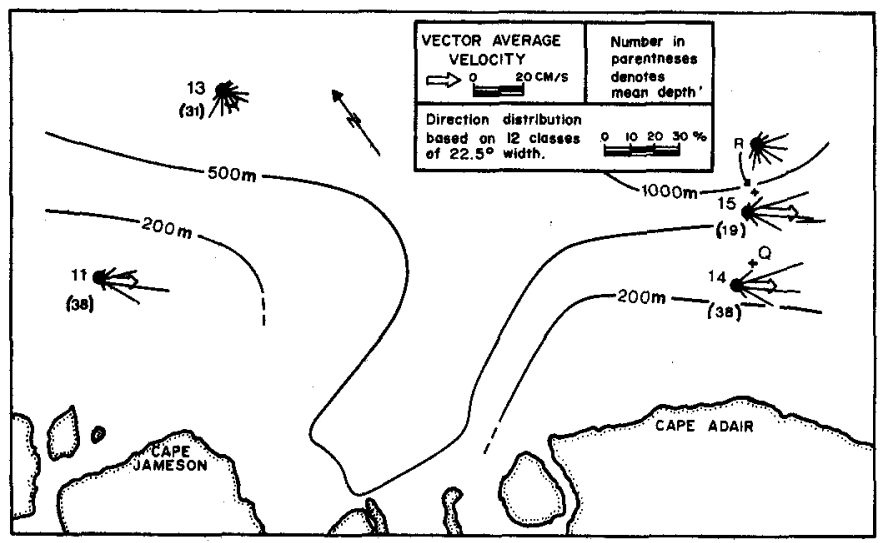

FIG. 30. The directional distribution of currents at nominal depths of 35 $m$ off the east coast of Baffin Island. Stations $11,13,14$ and 15 were operated in August and September 1978. Stations R and Q were operated in August and September 1979. (No distribution is shown for station Q because no $35 \mathrm{~m}$ record was recovered there).

TABLE 3. Statistics of current meter measurements off the east coast of Baffin Island.

\begin{tabular}{|c|c|c|c|c|c|c|c|}
\hline \multirow[b]{2}{*}{ Station } & \multirow[b]{2}{*}{$\begin{array}{c}\text { Mean } \\
\text { Depth } \\
\text { (m) }\end{array}$} & \multirow[b]{2}{*}{$\begin{array}{l}\text { Record } \\
\text { Length } \\
\text { (days) }\end{array}$} & \multicolumn{2}{|c|}{ Vector Average } & \multicolumn{2}{|c|}{ Speed } & \multirow{2}{*}{$\begin{array}{l}\mathrm{B}^{\mathrm{a}} \\
(\%)\end{array}$} \\
\hline & & & $\begin{array}{l}\text { Speed } \\
(\mathrm{cm} / \mathrm{s})\end{array}$ & $\begin{array}{c}\text { Direction } \\
\left({ }^{\circ} \mathrm{T}\right)\end{array}$ & $\begin{array}{l}\text { Mean } \\
(\mathrm{cm} / \mathrm{s})\end{array}$ & $\begin{array}{l}\operatorname{Max} \\
(\mathrm{cm} / \mathrm{s})\end{array}$ & \\
\hline
\end{tabular}

Nominal Depth: $35 \mathrm{~m}$

$\begin{array}{lccccccc}11 & 38 & 53 & 15.1 & 130 & 19.7 & 84.7 & 77 \\ 13 & 31 & 54 & 7.6 & 175 & 17.3 & 50.5 & 44 \\ 14 & 38 & 46 & 17.1 & 131 & 19.6 & 56.7 & 87 \\ 15 & 19 & 51 & 20.9 & 132 & 24.0 & 63.4 & 87 \\ \text { R } & (35) & 54 & 7.1 & 156 & 12.8 & 48.8 & 55\end{array}$

Nominal Depth: 125 and $250 \mathrm{~m}$

$\begin{array}{rcrrrrrr}11 & 126 & 47 & 4.7 & 134 & 8.5 & 40.4 & 55 \\ 13 & 254 & 54 & 4.8 & 180 & 7.8 & 27.8 & 62 \\ 14 & 126 & 52 & 8.4 & 139 & 10.2 & 32.6 & 82 \\ 15 & 234 & 51 & 10.9 & 126 & 11.4 & 37.6 & 96 \\ \text { Q } & 163 & 54 & 2.6 & 114 & 5.8 & 19.4 & 45 \\ \text { R } & (250) & 54 & 5.5 & 130 & 8.5 & 48.3 & 65\end{array}$

Nominal Depth: $500 \mathrm{~m}$

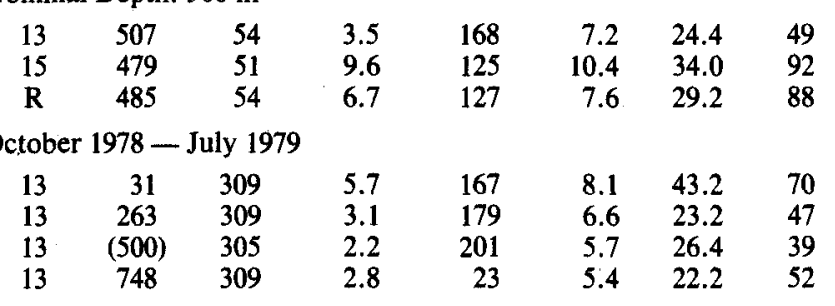

aThe steadiness factor $B$ is defined as the vector averaged speed divided by the mean speed times 100 percent (Ramster et al., 1978).
August-September 1978 measurement period. However, directional data at $750 \mathrm{~m}$ fell between southeasterly and southwesterly. Thus, it seems likely that the Baffin Current extends to depths of $750 \mathrm{~m}$ during the summer and autumn for considerable periods of time.

\section{SUMMARY}

A description has been presented of the major features of the summer near-surface circulation of Lancaster Sound and western Baffin Bay as they were observed in 1978 and 1979 during the EAMES project. In this paper, only the most important features have been described; a more detailed description may be found in Fissel et al. (1980).

Both 1978 and 1979 were unusually severe ice years, which raises the possibility that the circulation described in this paper is not typical of years with lesser ice cover. Fissel et al. (1980) have examined the available oceanographic data collected between 1950 and 1977 in Lancaster Sound and western Baffin Bay. These data offer poorer spatial resolution than the EAMES data. However, within those limits, the baroclinic surface circulation patterns computed from all the past data sets were found to be compatible with the patterns described in this paper.

The dominant feature of the summer near-surface circulation is the Baffin Current, which extends the full length of Baffin Bay. Originating with Arctic Ocean water which enters northern Baffin Bay through Smith, Jones and Lancaster sounds along with a possible contribution from the West Greenland Current, it flows southeastward along the western side of the bay. The swiftest part of the current is generally confined within $100 \mathrm{~km}$ of the coastline, and is subject to a number of perturbations, some of which are transient while others appear to be permanent.

The Baffin Current first appears in recognizable form off the east coast of Devon Island, becoming a strong flow about $25 \mathrm{~km}$ in width, centred 20 to $25 \mathrm{~km}$ offshore. Surface current speeds at the core of the current are about 40 $\mathrm{cm} / \mathrm{s}$, occasionally reaching $60 \mathrm{~cm} / \mathrm{s}$. At the southeastern tip of the island, speeds of $100 \mathrm{~cm} / \mathrm{s}$ are achieved. A major, apparently permanent, distortion of the Baffin Current occurs when it encounters the mouth of Lancaster Sound. It penetrates 35 to $75 \mathrm{~km}$ westward along the north side of the sound before crossing to the south side and exiting to the east. Throughout its excursion into Lancaster Sound, the Baffin Current maintains its character as a strong, well-defined flow, with surface speeds up to $75 \mathrm{~cm} / \mathrm{s}$, and an average width of 10 to $30 \mathrm{~km}$. There is some evidence that the width of the flow increases by perhaps a factor of 2 over the course of its excursion into the sound. The intrusion appears to have at least two semi-stable configurations which persist for periods of days or weeks.

Upon leaving Lancaster Sound, the Baffin Current turns southeastward to flow past Bylot Island, but frequently becomes detached from the coast at Cape Liverpool. As a result the area east of Bylot Island is the site of frequent 
meanders, eddies and northerly counterflows. In particular, anticyclonic eddies approximately $20 \mathrm{~km}$ in diameter are often found between the coast and a band of southerly flow 30 to $50 \mathrm{~km}$ offshore. South of Pond Inlet, the current once again becomes relatively stable and well-defined. The core of the current, which has surface speeds of about $30 \mathrm{~cm} / \mathrm{s}$ (occasionally reaching $60 \mathrm{~cm} / \mathrm{s}$ ), follows the continental slope down the length of Baffin Island. The path of the current is essentially steady, with some small perturbations in the form of meanders.

The circulation of the region is also subject to important temporal variations, with periods ranging from several hours to a year or longer. Tidal flows and inertial oscillations, derived from the EAMES data, are presented in Fissel (1982). Seasonal variations of the Baffin Current are discussed by Lemon and Fissel (1982). In addition to its seasonal fluctuations, some features of the Baffin Current appear to change significantly over times ranging from a few days to several weeks. One example of such variability is the alternate patterns of the intrusive current in eastern Lancaster Sound. Shifts in the current were also evident off the east coasts of Devon and Bylot islands over similar time scales.

Outside the boundaries of the Baffin Current, the flows are generally weaker or less steady. To the east of the intrusion into Lancaster Sound, near-surface currents appear to be relatively weak and disordered. In western and central Lancaster Sound, the currents were strong at times but did not exhibit any stable, spatially coherent pattern. Based on the fate of released drifters, the net flow of this region appears to be easterly.

The Baffin Current is a major oceanographic feature of the eastern Arctic. Knowledge of its structure is vital to an understanding of the marine transport of pollutants, sea ice, icebergs and biological organisms. It is a major influence in eastern Lancaster Sound, an area which sustains a remarkably high biological productivity for arctic waters. A large quantity of oceanographic data on the Baffin Current was collected by the EAMES project. In the analysis to date, emphasis has been placed on describing the surface and near-surface circulation for the purposes of environmental impact assessment of exploratory drilling. This paper has provided a description of some of those observations; some other aspects of the oceanography are described in other papers in this volume (Fissel, 1982; Lemon and Fissel, 1982; Marko et al., 1982). Much data of more purely scientific interest remain to be explored.

\section{ACKNOWLEDGEMENTS}

This study was sponsored by Petro-Canada and represents a major component of the multi-disciplinary Eastern Arctic Marine Environmental Studies (EAMES) program. Many people and organizations assisted us in carrying out our studies. Specifically, we wish to thank: Messrs. G. Glazier and H. Hume and Drs.
R. Wallace, E.B. Bennett and J.-M. Sempels of Petro-Canada for their unfailing support and assistance throughout the study; Captains Kjell Marö and George Parnell, Chief Officer Karl Egert, Chief Engineer Frank Daw, the officers and crew of the M/V Theron for their dedication during two extended cruises to Baffin Bay in 1978 and 1979; George Koenig, Ray Shurmer, Sandy McKenzie and Paul Idlout of Petro-Canada for their logistical support from the land base at Pond Inlet, N.W.T.; Gary Wilton, Robert Kelly and Will Bailey of Arctic Sciences Ltd. who were instrumental in ensuring successful field programs and high data recovery rates; and Colin Foster, Doug Knight, Doug Say and Leo Ford of Arctic Sciences Ltd. for their dedication in processing the large quantity of oceanographic data collected in the course of this study.

\section{REFERENCES}

BAILEY, W.B. 1957. Oceanographic features of the Canadian archipelago. Journal of the Fisheries Research Board of Canada 14:731-769.

BARBER, F.G. and HUYER, A. 1977. On the oceanography of Jones Sound, N.W.T. Marine Sciences Branch Manuscript Report Series No. 40. Ottawa. 48 p.

BARNES, C.A. 1941. Oceanographic investigations in Baffin Bay in 1940. United States Coast Guard Bulletin 30:27-56.

BIRCH, J.R. 1980a. Data Report No. 5: 1979 Nearshore studies of the physical oceanography of Cape Warrender, Cape Fanshawe and Cape Hay. Unpublished manuscript. Arctic Sciences Ltd., Sidney, B.C. 30 p. plus appendices. [Available from Pallister Resource Management Ltd., 700 - 6 Ave. S.W., Calgary, Alberta.]

1980b. Data Report No. 6: Analysis of water level record for Johnson Bay, N.W.T., Aug. 22, 1978-May 12, 1979. Unpublished manuscript. Arctic Sciences Ltd., Sidney, B.C. 17 p. plus appendices. [Available from Pallister Resource Management Ltd., 700 - 6 Ave. S.W., Calgary, Alberta.]

COLLIN, A.E. 1962. On the oceanography of Lancaster Sound. Unpublished Ph.D. thesis, McGill University, Montreal.

DUNBAR, M.J. 1951. Eastern Arctic waters. Fisheries Research Board of Canada Bulletin No. 88, Ottawa. 131 p.

DUNBAR, M. and NUTT, D.C. 1967. The Baffin Bay - North Water Project, Report No. 1. Research Paper No. 45. Montreal: Arctic Institute of North America. 71 p.

FISSEL, D.B. 1980. Data Report No. 2: Satellite-tracked drifting buoy movements in Baffin Bay and Lancaster Sound, summer 1978 and 1979. Unpublished manuscript. Arctic Sciences Ltd., Sidney, B.C. 40 p. plus appendices. [Available from Pallister Resource Management Ltd., 700 - 6 Ave. S.W., Calgary, Alberta.]

1982. Tidal currents and inertial oscillations in northwestern Baffin Bay. Arctic 35 (this issue).

and BIRCH, J.R. 1980. Data Report No. 4: Current profile measurements in western Baffin Bay and Lancaster Sound, summers 1978 and 1979. Unpublished manuscript. Arctic Sciences Ltd., Sidney, B.C. 17 p. plus appendices. [Available from Pallister Resource Management Ltd., 700 - 6 Ave. S.W., Calgary, Alberta.]

FISSEL, D.B., LEMON, D.D. and BIRCH, J.R. 1980. The physical oceanography of western Baffin Bay and Lancaster Sound. Unpublished manuscript submitted to Petro-Canada. Arctic Sciences Ltd., Sidney, B.C. 345 p. [Available from Publications Inquiry Section, Department of Indian Affairs and Northern Development, Ottawa, Ontario K1A 0H4.]

FISSEL, D.B. and MARKO, J.R. 1978. A surface current study of eastern Parry Channel, N.W.T., summer 1977. Unpublished manuscript. Arctic Sciences Ltd. Contractor Report Series 78-4, Institute of Ocean Sciences, Sidney, B.C.

FISSELL, D.B. and WILTON, G.R. 1978. Surface current measurements in eastern Lancaster Sound, N.W.T. - summer 1977. Unpublished manuscript. Arctic Sciences Ltd. Contractor Report Series 78-3, Institute of Ocean Sciences, Sidney, B.C. 72 p. 
1980. Data report No. 1: Subsurface current measurements in western Baffin Bay and Lancaster Sound, 1978-79. Unpublished manuscript. Arctic Sciences Ltd., Sidney, B.C. 52 p. plus appendices. [Available from Pallister Resource Management Ltd., 700 - 6 Ave. S.W., Calgary, Alberta.]

HERLINVEAUX, R.H. 1974. Surface movements in Canadian arctic waters with some accompanying temperature and salinity observations. Unpublished manuscript. Pacific Marine Science Report, Institute of Ocean Sciences, Sidney, B.C, 36 p.

KIILERICH, A.B. 1939. A theoretical treatment of hydrographical observational material, Godthaab Expedition. Meddelelser om Grønland 78:1-148

LEMON, D.D. 1980. Data Report No. 3: CTD data from western Baffin Bay and Lancaster Sound, 1978 and 1979. Vol. I and Vol. II. Unpublished manuscript. Arctic Sciences Ltd., Sidney, B.C. 52 p. plus appendices. [Available from Pallister Resource Management Ltd., 700 - 6 Ave. S.W., Calgary, Alberta.]

and FISSEL, D.B., 1982. Seasonal variations in currents and water properties in northwestern Baffin Bay 1978-1979. Arctic 35 (this issue).
MARKO, J.R. 1981. The ice environment of eastern Lancaster Sound and western Baffin Bay. Unpublished manuscript prepared for PetroCanada by Arctic Sciences Ltd., Sidney, B.C. 195 p. plus appendices. [Available from Publications Inquiry Section, Department of Indian Affairs and Northern Development, Ottawa, Ontario K1A 0H4.]

, BIRCH, J.R. and WILSON, M.A. 1982. A study of long-term satellite-tracked iceberg drifts in Baffin Bay and Davis Strait. Arctic 35 (this issue).

MUENCH, R.D. 1971. The physical oceanography of the northern Baffin Bay Region. Baffin Bay - North Water Project Scientific Report No. 1. Washington, D.C.: Arctic Institute of North America. 150 p.

RAMSTER, J.W., HUGHES, D.B. and JURNES, G.K. 1978. A steadiness factor for estimating the variability of residual drifter in current meter records. Deutsche Hydrographische Zeitschrift 31:230-236.

RIGGS, N.P. THANGAM BABU, P.V., SULLIVAN, M.A. and RUSSELL, W.E. 1980. Iceberg drift observations in Lancaster Sound. Cold Regions Sciences and Technology 1:283-291.

WALKER, E.R. 1977. Aspects of oceanography in the archipelago. Unpublished manuscript. I.O.S. Note. 3, Institute of Ocean Sciences, Sidney, B.C. 186 p. 